\title{
Potential Competitive Effects of Basel II on Banks in SME Credit Markets in the United States
}

\author{
Allen N. Berger \\ Board of Governors of the Federal Reserve System, Washington, DC 20551 U.S.A. \\ Wharton Financial Institutions Center, Philadelphia, PA 19104 U.S.A. \\ aberger@,frb.gov
}

February 2004

\begin{abstract}
$\underline{\text { Abstract }}$
We examine the likely competitive effects of the proposed implementation of the Basel II capital requirements on banks in the market for credit to SMEs in the U.S. Specifically, we address whether reduced risk weights for SME credits extended by large banking organizations that adopt the Advanced Internal Ratings-Based (AIRB) approach of Basel II might significantly adversely affect the competitive positions of organizations that do not adopt A-IRB. The analyses suggest only a relatively minor competitive effect on the majority of community banks primarily because the organizations that are likely to adopt A-IRB tend to make very different types of SME loans to different types of borrowers than community banks. However, the analyses suggest the possibility of significant adverse effects on the competitive positions of large banking organizations that do not adopt A-IRB because the data do not suggest any strong segmentation in SME credit markets among large organizations.
\end{abstract}

JEL Classification Numbers: G21, G28, G38, L51

Keywords: Banks, Capital Requirements, SMEs, Basel II

The opinions expressed do not necessarily reflect those of the Federal Reserve Board or its staff. The author thanks seminar participants from the Board of Governors of the Federal Reserve System, Federal Deposit Insurance Corporation, Federal Reserve Bank of Philadelphia, Office of the Comptroller of the Currency, and Office of Thrift Supervision, as well as Bob Avery, Tom Brady, Paul Calem, Brad Case, Ed Ettin, Jim Follain, Diana Hancock, Tim Hannan, Erik Heitfield, Bev Hirtle, Jim Houpt, Dave Jones, Myron Kwast, David Palmer, Steve Pilloff, Bill Treacy, David Wright, and Egon Zakrajsek for helpful comments. Phil Ostromogolsky provided outstanding research assistance. 


\section{Introduction}

This paper examines the likely competitive effects of the proposed bifurcated implementation of the Basel II risk-based capital requirements on banks in the market for credit to small and medium enterprises (SMEs) in the U.S. In particular, an issue has been raised as to whether a reduction in the implicit risk weights for SME credits extended by the large banking organizations that adopt the Advanced Internal Ratings-Based (A-IRB) approach of Basel II might significantly adversely affect the competitive position of community banks, often defined empirically as institutions with under $\$ 1$ billion in assets. In addition, some have expressed concern that large banking organizations that do not adopt A-IRB may also be put at competitive disadvantages. This paper focuses solely on such potential competitive effects on banks in the SME credit market and does not address the issue of the accuracy of the implicit risk weights.

As a brief background, under Basel II as the U.S. agencies have currently proposed for U.S. institutions, a bifurcated capital regulatory system would be created. U.S. banking organizations that adopt the A-IRB approach would face higher or lower required capital ratios for SME loans and other financial instruments depending on perceived risks of the credit instruments, while non-A-IRB institutions' regulatory capital requirements would continue to be determined by the Basel I risk weights. Under the current proposal, U.S. banking organizations with total banking (and thrift) assets of at least $\$ 250$ billion or at least $\$ 10$ billion in on-balance-sheet foreign exposures - about 10 large organizations based on current balance sheets - would be required to adopt A-IRB. ${ }^{1}$ Other banking organizations may also choose to adopt A-IRB if they meet infrastructure requirements. Organizations may "opt in" because they expect to grow into the size requirements, because the perceived benefits of the net change in capital requirements exceed the expected costs of adjusting risk management systems to conform with the A-IRB requirements, or because of other factors.

Adoption of A-IRB would affect the required capital ratios of the bank holding company (BHC), all large banks in the BHC, and in most cases, any small banks that may also be in the organization. Under the Basel II proposal, the required capital for an SME loan would depend on a number of factors, including the probability of default (PD) and loss given default (LGD) assigned by the bank, whether the loan is classified

\footnotetext{
${ }^{1}$ On August 4, 2003, U.S. banking regulators circulated an Advance Notice of Proposed Rulemaking (ANPR) for the application of Basel II to U.S. banking organizations. See Board of Governors et al. (2003) for the press release, ANPR, and other information.
} 
as retail or corporate, and the size of the borrowing firm. To receive relatively favorable treatment as a retail exposure (i.e., lower requirements than large corporate loans primarily due to use of lower asset correlations), the total exposure of the banking organization to the SME must be under $€ 1$ million and the credit must be managed as a retail exposure or be guaranteed by an individual. For corporate loans, there may also be a favorable SME "carve-out," involving the use of lower asset correlations in some circumstances for exposures to firms with under $€ 50$ million in sales. ${ }^{2}$ U.S. agencies have the options of eliminating the favorable retail exposure or "carve-out" treatments, given that any country may impose higher capital requirements than the international standards.

The implementation of Basel II theoretically could adversely affect the competitive position of community banks or other large banking organizations that do not adopt A-IRB in the SME credit market because it may reduce the minimum regulatory capital, potentially lowering the marginal costs of SME lending for A-IRB adopters. ${ }^{3}$ The substitution effect of a decline in marginal costs at A-IRB banks relative to non-A-IRB banks could possibly encourage A-IRB banks to reduce price and/or increase quantity of SME lending, potentially reducing the price received by community banks or other large banking organizations on SME loans and/or cutting the market shares of these institutions. ${ }^{4}$

The magnitudes of these potential outcomes - if they exist - depend on several factors. Based on the research discussed below, a key factor with regard to the competitive effects on community banks appears to be the comparative disadvantage of large banking organizations in making relationship loans to informationally opaque SMEs. Large banking organizations tend to have comparative advantages in transactions loans to relatively transparent SMEs and community banks tend to have comparative advantages in relationship lending to relatively opaque SMEs, suggesting that the competitive effects on most community banks may be relatively limited. ${ }^{5}$ In contrast, the very large banking organizations that adopt A-IRB may not

\footnotetext{
${ }^{2}$ See Basel Committee on Bank Supervision (2002) for the details of the proposal.

${ }^{3}$ As discussed below, banking organizations generally hold capital buffers above regulatory minimums to allow them to exploit unexpected future opportunities and to cushion the effects of unexpected future negative shocks, so a change in regulatory minimums may affect marginal costs even for organizations that are above the regulatory minimums.

${ }^{4}$ This paper focuses only on the substitution effect. The adoption of Basel II could also have competitive implications due to income effects if the A-IRB banking organizations use the cost savings or reduced capital requirements to merge with or acquire other community banks or other institutions. However, recent research suggests that the income effect is likely to be quite limited (Hannan and Pilloff 2004).

5 "Relationship" and "transactions" loans are defined below.
} 
have significant comparative advantages or disadvantages in SME lending relative to most other large banking organizations that do not adopt A-IRB. As a result, it is possible that the competitive effects on these other large institutions in the SME lending market may be significant, although there may also be some mitigating factors. Importantly, the competitive effects on some small and large banking organizations may differ to the extent that some large banking organizations tend to behave like community banks and specialize in relationship loans, and/or to the extent that some small banks tend to be behave more like large banking organizations and specialize in transactions loans.

The analysis proceeds as follows. In Section 2, we review the extant research literature on SME lending by large banking organizations and community banks. The research literature provides evidence on the comparative advantages of the different sizes of institutions and how these comparative advantages help sort SME customers among banks and provide separate market niches for both community banks and large organizations. The literature suggests that large banking organizations make different types of SME loans than community banks, so that the competitive effects on community banks are likely to be relatively small in most cases unless the marginal cost benefits to A-IRB banks for the types of SME loans made by community banks are relatively large.

In Section 3, we analyze recent U.S. data on banking organization size and SME lending to see if it remains consistent with the research literature about large banking organizations versus community banks. We also perform three analyses that do not generally appear in the literature. First, we compare internal risk ratings assigned to individual SME loans by banking organizations of different sizes. Second, we compare SME loan characteristics among various sizes of large institutions to test for different comparative advantages in SME lending between the very large institutions that are likely to adopt A-IRB and other large institutions that may not adopt it. Third, we look more closely at the characteristics of SME loans made by individual banks. Specifically, we examine the extent to which a minority of banks in organizations that are likely to adopt A-IRB may behave like community banks, and the extent to which a minority of small banks that are typically labeled as community banks may behave more like large banking organizations in their SME lending. The empirical findings generally reinforce those in the literature regarding the different types of SME loans made by likely A-IRB banks and by community banks. The data raise the possibility that a significant minority of small banks may behave more like large banking organizations in their SME lending, 
but do not provide strong evidence on this issue and are highly uncertain due to data limitations. The findings do not suggest substantial differences in lending behavior between likely A-IRB banks and other large banking organizations. Thus, one cannot reject the hypothesis that a relatively small change in marginal costs may have significant competitive effects on many of these other large institutions.

In Section 4, we briefly examine how A-IRB adoption may affect the marginal costs of SME lending. It is not possible to accurately estimate these marginal cost effects, but as a second-best alternative, we obtain a rough estimate of an upper bound to the magnitude of the marginal cost effect for the average A-IRB bank. This rough upper bound appears to be too small for the proposed change in capital requirements on SME loans to have significant effects on the competitive positions of most community banks in SME lending markets, but it may be large enough to have significant effects in some cases on the competitive positions of banks in large organizations that do not adopt A-IRB.

Section 5 gives our conclusions.

\section{Review of the relevant research literature on banking organization size and SME lending}

This section reviews some of the extant research literature on SME lending by large banking organizations and community banks. The research suggests that community banks have comparative advantages in relationship lending based on qualitative information to informationally opaque SMEs, and large institutions have comparative advantages in transactions lending based on quantitative information to more transparent borrowers. As well, the literature generally finds that in local U.S. banking markets, these comparative advantages and disadvantages help sort SME customers among banks and provide separate market niches for both community banks and large organizations.

\subsection{Differences in lending technologies}

Transactions lending technologies - such as financial statement lending, asset-based lending, and small business credit scoring - are primarily based on "hard" quantitative data. These transactions lending technologies are distinguished primarily by the source and type of information used -1) financial ratios for

financial statement lending; 2) the quantity and quality of the available collateral - usually accounts receivable and inventory - for asset-based lending; and 3) the financial condition and history of the principal owner of the firm for small business credit scoring (Berger and Udell 2002). The information used in transactions lending is generally relatively transparent and is easily observable and verified at the time of the 
credit origination. Only relatively informationally transparent SMEs that have high-quality financial statements, high-quality collateral, and/or owners with high-quality past performance generally receive transactions credit from banks.

Relationship lending technology, in contrast, is based in large part on "soft" information, such as the character and reliability of the firm's owner, the history of the firm's relationships with its suppliers, and the business prospects in the local neighborhood in which the firm operates. The information is generally gathered through contact over time by the bank loan officer with the firm, its owner, its suppliers, its customers, and its local community on a variety of dimensions. The SMEs with relationship credit are generally informationally opaque, without sufficient high-quality quantitative and verifiable hard information on which to base the credit.

The literature suggests a number of reasons why large and small banking organizations may have comparative advantages in different types of SME loans to different customers using different lending technologies. Large banking organizations may have comparative advantages in transactions technologies to relatively transparent SMEs because of economies of scale in the processing of quantitative information. Community banks are likely to have comparative advantages in relationship lending to informationally opaque SMEs because the soft information on which the credits are based is difficult to quantify and transmit through the communication channels of large banking organizations (e.g., Stein 2002). As well, because the loan officer that deals directly with the SME, its owner, and other local market participants is the primary repository of the soft information, agency problems may be created within the banking organization that may best be resolved by structuring the bank as a small, closely-held organization with few managerial layers (e.g., Berger and Udell 2002). Such organizational arrangements are generally inconsistent with the structure needed by large banking organizations. It is also often argued that large banking organizations are disadvantaged at extending relationship loans to informationally opaque SMEs because of organizational diseconomies of providing relationship lending services along with providing transactions lending services and other wholesale services to their large corporate customers (Williamson 1967, 1988).

\subsection{Differences in SME loans by banking organization size}

Turning to the empirical literature, the data indicate numerous differences in the SME loans made by large banking organizations and community banks. These differences are generally consistent with the 
hypothesis that large institutions tend to make transactions loans to relatively transparent SMEs and community banks tend to make relationship loans to informationally opaque SMEs. Relative to community banks, large banking organizations in the U.S. have been found to lend to larger, older, more financially secure SMEs (e.g., Haynes, Ou, and Berney 1999). Such SMEs are typically the types of relatively transparent firms that are expected to receive transactions credits.

Larger banking organizations have also been found to charge significantly lower interest rates and earn lower yields on the SME loans that they make (e.g., Hannan 1991, Berger and Udell 1996, Berger, Rosen, and Udell 2003, Carter, McNulty, and Verbrugge 2004). The lower loan rates charged by large institutions most likely reflect lower risks because relatively transparent SMEs with sufficient hard information to obtain bank credit may generally be less risky than relatively opaque SMEs whose credit is primarily based on soft information. The lower rates may also reflect to some extent lower operating costs because the processing of hard information may be generally less costly than the processing of soft information. To some extent, lower rates may reflect lower marginal funding costs, because large organizations may generally be more diversified and have access to more funding sources. Finally, the lower rates may to some degree reflect less market power, because hard information may generally be less proprietary to the lender than soft information. Thus, transactions loans based primarily on hard information to relatively transparent SMEs made by large banking organizations may be generally less risky, less costly, and/or involve less market power than relationship loans based on soft information to relatively opaque SMEs made by community banks. However, there are some potentially important exceptions to these generalities. In particular, such patterns may be less likely to hold for some asset-based credits and credits generated by small business credit scoring than for most financial statement loans. Asset-based loans are often quite risky and involve costly monitoring of accounts receivable and inventory, and loans issued using small business credit scoring may in some cases be relatively risky. Nonetheless, we expect that on average, transactions loans have lower interest rates than relationship loans due to lower risk, lower operating costs, and/or lower market power.

SME loans made by large banking organizations have also been found to have collateral pledged less often (e.g., Berger and Udell 1996). Although pledging collateral reduces loan risk, secured loans often have higher risk than other loans because they tend to be issued to relatively risky, informationally opaque 
borrowers for the purpose of controlling adverse selection and moral hazard problems (e.g., Berger and Udell 1990). Therefore, the finding of less frequently pledged collateral on SME credits issued by large banking organizations is consistent with transactions lending to relatively safe, transparent SMEs.

Large banking organizations have also been found to have temporally shorter and less exclusive relationships with their SME loan customers (e.g., Berger, Miller, Petersen, Rajan, and Stein 2002). These are more likely to be transactions credits, since relationship lending typically involves longer relationships and having a single institution with the proprietary soft information provide all of the bank credit to the SME.

In addition, larger banking organizations have been found to lend more often on an impersonal basis and at a longer distance (e.g., Berger, Miller, Petersen, Rajan, and Stein 2002). Presumably, relationship lending is associated with more personal contact at shorter distances.

Finally, large banking organizations have been found to base their SME lending decisions more on financial ratios than on prior relationships (e.g., Berger, Miller, Petersen, Rajan, and Stein 2002, Cole, Goldberg, and White forthcoming). The use of hard information such as financial ratios is more associated with transactions lending to relatively transparent SMEs, and the use of soft information from existing relationships is more associated with relationship lending to relatively informationally opaque SMEs.

\subsection{Evidence on the sorting of SME borrowers across banks}

In sum, a fairly large body of research suggests that large banking organizations and community banks tend to make different types of SME loans consistent with the comparative advantages discussed above. We next review research evidence that these comparative advantages are quantitatively important in sorting SME loan customers across institutions.

One piece of evidence often cited to support the hypothesis that large banking organizations have comparative disadvantages at relationship lending to SMEs - or SME lending altogether - is the finding that large institutions have much smaller ratios of SME loans to assets than do community banks (e.g., Berger, Kashyap, and Scalise 1995, Keeton 1995, Strahan and Weston 1996). These ratios by themselves are not convincing evidence of a strong comparative disadvantage for large banking organizations because of the use of assets in the denominator. Large institutions could have more SME loans than community banks under the same market circumstances, and simply have disproportionately even more of other types of assets, such as large corporate loans. That is, the low SME loans to assets ratio suggests only that large banking 
organizations may be disadvantaged in SME lending relative to other types of lending or asset investments, but does not rule out that these organizations may be superior to community banks at both SME lending and large corporate loans and other activities. As shown below, large banking organizations in fact make a substantial proportion of the SME loans in the nation, despite devoting relatively small proportions of their asset portfolios to these credits.

However, other evidence on the dynamic effects of bank consolidation is more convincing that large banking organizations are significantly disadvantaged in at least some types of SME lending. The SME loanto-assets ratio tends to decline significantly after large banking organizations are involved in mergers and acquisitions (M\&As), consistent with the consolidating institutions reducing their supplies of at least some types of SME credit (e.g., Berger, Saunders, Scalise, and Udell 1998, Peek and Rosengren 1998, Strahan and Weston 1998). Further evidence suggests that these customers may be sorted to other institutions that have comparative advantages in serving them. In particular, after M\&As of large institutions that reduce their SME lending, the total supply of this SME credit in their local markets appears not to change substantially because of "external effects" or general equilibrium reactions of other banks. Other banks in the same local markets appear to respond by increasing their own supplies of SME credit (e.g., Berger, Saunders, Scalise, and Udell 1998, Berger, Goldberg, and White 2001, Avery and Samolyk 2004). As well, new small banks (de novo entrants) are often created that tend to devote large portions of their portfolios to SME loans (Berger, Bonime, Goldberg, and White 2004).

Other evidence is also consistent with the hypothesis that SME borrowers are sorted among the banks. Studies have found that the local market shares of large institutions and community banks have little association with SME credit availability in the markets, consistent with informationally opaque SMEs finding credit at other local institutions when it is not available from large institutions (Jayaratne and Wolken 1999, Berger, Rosen, and Udell 2003). One study also found more general flexibility in SME lending markets. Specifically, when large or small banks encountered capital shortfalls that decreased their SME lending during the credit crunch of the early 1990s, other banks tended to increase their SME lending in the same U.S. state (Hancock and Wilcox 1998).

\subsection{Implications from the research literature}

The findings in the research literature summarized here strongly suggest that large banking 
organizations and community banks tend to have comparative advantages in different types of SME lending and that these comparative advantages are quantitatively important in sorting SME loan customers across institutions. These findings suggest that the change in capital requirements on SME loans for the very large institutions that adopt A-IRB is not likely to have significant effects on the competitive positions of community banks in SME lending markets unless the marginal cost benefits to A-IRB banks for the types of SME loans made by community banks are relatively large (a topic addressed in Section 4 below). Community banks generally make different types of SME loans to different customers using different lending technologies and market forces tend to be powerful in allocating these loans to community banks.

A significant drawback of this literature is that it sheds very little light on the potential effects of the change in minimum regulatory capital requirements on SME loans for A-IRB adopters on the competitive positions in SME lending markets of large banking organizations that do not adopt A-IRB. The extant literature generally compares large banking organizations and community banks, but generally does not compare the SME lending behavior of the very large institutions that are likely to adopt A-IRB with other large institutions that may not adopt, leaving open the possibility of significant competitive effects. ${ }^{6}$ In the next section, we address this additional issue by comparing SME loan characteristics among different sizes of large institutions.

\section{Empirical analysis of recent data on banking organization size and SME lending}

In this section, we analyze recent U.S. data on banking organization size and SME lending to see if they remain consistent with the stylized facts from the research literature about large institutions versus community banks. We also perform three analyses that do not generally appear in the literature.

First, we include comparisons of the internal risk ratings assigned to individual SME loans by banking organizations of different sizes. To our knowledge, there have been no previous analyses of how these risk ratings differ by bank size. If large banking organizations and community banks assign internal risk ratings to SME loans differently, this might be additional evidence that different sizes of banking organizations use different lending technologies or otherwise have different comparative advantages in SME lending.

\footnotetext{
${ }^{6}$ One exception to this is that the literature on the ratio of SME loans to assets does compare these ratios across a number of size classes with the finding that the ratio declines monotonically as banking organization size increases. However, as noted above, this evidence by itself is not very convincing because of the use of assets in the denominator.
} 
Second, we compare SME loan characteristics among various sizes of large institutions to try to determine if there are significant differences in the comparative advantages in SME lending between the very large institutions that are likely to adopt A-IRB and other large institutions that may not adopt it. If all large institutions tend to make the same types of SME loans, then it is more likely that the implementation of Basel II will have significant competitive effects on these other large institutions in the market for credit to SMEs and vice versa if the two size classes of large banking organizations make different types of SME loans.

Third, we go beyond the usual regression analyses of the average effects of banking organization size and look more closely at the characteristics of SME loans made by individual banking organizations. It is possible, for example, that a significant minority of very large institutions that are likely to adopt A-IRB tend to have SME loan portfolios with similar characteristics on average to those of community banks. Similarly, it could be the case that a significant minority of small banks may have SME portfolios that are more like those of large banks than community banks. If it turns out that a significant minority of very large institutions have SME loan portfolios similar to those of community banks, then there may be a larger effect on the competitive position of community banks from the implementation of Basel II than may be suggested by the extant literature and by the means and regressions presented here. Similarly, if a significant minority of small banks that are typically labeled as community banks have SME portfolios that are more like large banks, then there may be significant competitive effects on this minority of small banks that are not apparent from the literature or full-sample statistics here.

\subsection{Data and variables}

We use data from the June 2002 Call Report and the May 2002 Survey of Terms of Bank Lending to Businesses (STBL) to see if there are differences in the quantities and types of SME loans issued by banking organization size. Among other data, the June Call Report has information on small loan quantities and the STBL has information on contract terms of individual commercial loans - such as interest rates, repayment dates, collateral, and commitment status - and the bank's internal risk ratings of each of these loans. The June Call Report is available for virtually all banks, and the STBL covers approximately 300 U.S. banks per quarter, and obtains data on new domestic commercial loans issued by these banks during one or more days of the first week of the second month of the quarter. The STBL survey oversamples the largest banks, and thus includes more of the banks in entities that are likely to adopt A-IRB. In some cases, the STBL respondents 
give information on loan contract terms, but not the risk ratings.

We perform the analysis by individual bank, rather than the bank holding company (BHC), since it is banks that respond to the STBL survey. In many cases, one or more banks in a top-tier BHC are STBL respondents and one or more banks in the same BHC are not respondents, so it is not possible to perform the analysis at the BHC level. Nonetheless, we do analyze the effect of banking organization size at the consolidated entity level, where entity size is measured by the combined gross total assets (GTA) as of June 2002 of all the banks in the top-tier BHC if the bank is in a BHC, and the GTA of the bank if the bank is not in a BHC.

We assign each bank to one of four entity size classes - Top 20, Entities 21-50, Other Large, and Community - based on GTA of the entity. Top 20 refers to the largest 20 U.S. entities, Entities 21-50 includes the next 30 largest entities, Other Large is composed of all other U.S. entities with GTA $>$ \$1 billion, and Community indicates entities with GTA $\leq \$ 1$ billion (all financial values in current 2002 dollars). Top 20 roughly corresponds to banks that are part of entities that are most likely to adopt A-IRB. As noted above, about 10 large banking organizations based on current balance sheets would be required to adopt A-IRB. The other 10 entities in the Top 20 size class may be the most likely institutions to opt into A-IRB or to grow to a size at which A-IRB adoption would be required, so these institutions are also included in the largest size class. A preliminary analysis that separated the top 10 from entities 11-20 found that both sets of entities had similar SME loan characteristics. Entities 21-50 is designed to represent other large banking organizations that may or may not choose to adopt A-IRB, depending on many factors, likely including a comparison of the expected costs of adjusting risk management systems to conform with the A-IRB infrastructure requirements versus the perceived benefits - if any - of the net change in capital requirements. Other Large is intended to represent other large banks that may not be likely to opt to adopt A-IRB, and Community is intended to represent community banks. Thus, the data allow comparisons of banks in entities likely to adopt A-IRB with both community banks and with banks in large entities that may or may not adopt A-IRB. As shown in Table 1 below, the ranges of entity GTA for the Top 20, Entities 21-50, Other Large, and Community size classes are approximately $\$ 57.9 \mathrm{~B}-\$ 619.8 \mathrm{~B}, \$ 16.8 \mathrm{~B}-\$ 56.2 \mathrm{~B}, \$ 1.0 \mathrm{~B}-\$ 16.6 \mathrm{~B}$, and $\$ 1 \mathrm{M}-\$ 999 \mathrm{M}$, respectively, where $\mathrm{B}$ refers to billions and $\mathrm{M}$ refers to millions.

Importantly, the size classes are constructed on the basis of all banks that filed June 2002 Call 
Reports, whether or not they reported their small commercial loan quantities on the June Call, and whether or not they reported loan contract terms or risk ratings on the May 2002 STBL. In principle, we could have more or less than 20 banks in the Top 20 size class and more or less than 30 banks in the Entities 21-50 size class for any particular set of variables, depending on the number of banks in each of the multibank BHCs, and the number of these that file the various reports. As shown below, in the Top 20 entity size class, there are 130 banks for measuring SME loan quantities (about 6.5 banks per entity), 35 banks for measuring SME loan contract terms, and 32 banks for measuring SME loan risk ratings. Similarly, in the Entities 21-50 size class, there are 134 banks, 23 banks, and 19 banks for measuring quantities, contract terms, and risk ratings, respectively.

Following the literature, we measure SME loans as commercial credits under $\$ 1$ million, inclusive of the amount of the commitment under which the loan was drawn (if any). This also corresponds fairly well with one of the requirements for favorable treatment as a retail exposure under A-IRB - total exposure to the SME of under $€ 1$ million. We acknowledge that in some cases these may be small credits to large businesses. To check robustness, we also divide the SME loan data into credit size classes of $\leq \$ 100 \mathrm{~K}, \$ 100 \mathrm{~K}-\$ 250 \mathrm{~K}$, and $\$ 250 \mathrm{~K}-\$ 1 \mathrm{M}$ ( $\mathrm{K}$ indicates thousands, and $\mathrm{M}$ indicates millions) to allow for possible differences in competitive effects by credit size class. One reason for potential differential effects is that the small business credit scoring technology (SBCS) - one of the transactions lending technologies often used by large banking organizations - is often applied only to credits under $\$ 100 \mathrm{~K}$, or sometimes also to credits in the $\$ 100 \mathrm{~K}$ \$250K range (see Frame, Srinivasan, and Woosley 2001). In addition, some research found significantly different effects of SBCS on the lending behavior of large banks for credits of $\$ 100 \mathrm{~K}$ - $\$ 250 \mathrm{~K}$ versus credits $\leq \$ 100 \mathrm{~K}$ (Berger, Frame, and Miller forthcoming). There may also be other differences among the credit sizes under $\$ 1 \mathrm{M}$ in the transparency of borrowers or other characteristics that affect the comparative advantage of banks in different size classes. Finally, the size of the SME credit is also likely to be correlated with the sales of the firm, which may affect whether the loan receives favorable treatment under the SME "carve-out" discussed above.

Table 1 shows the definitions of the variables. The SME-RATIO variables indicate the proportions of bank assets devoted to SME credits of the various sizes, constructed from the June 2002 Call Report. The banking entity size classes, Top 20, Entities 21-50, Other Large, and Community, are constructed from the 
same Call Report. As noted above, all of the variables are measured at the bank level, although the organization size into which the bank is classified is based on the entire consolidated banking entity (including the assets of all banks in the same top-tier BHC, if any).

The contract terms on individual loans include PREMIUM, COLLATERAL, COMMITMENT, DURATION, and CREDIT SIZE, constructed from the May 2002 STBL. The premium over the Treasury rate of comparable repayment duration, PREMIUM, likely mainly embodies the bank's assessment of loan risk, operating costs, and/or market power (if any). As discussed in the literature review above, the other contract terms are indicators of important differences in contract terms that may affect the risk of the loan and may also be used by banks to differentiate among risk pools under asymmetric information and so may reflect differences in risk or informational opacity. As noted in Table 1, we delete observations for which measured PREMIUM was less than -0.01 (interest rate more than 1 percentage point below the corresponding Treasury rate) or greater than 0.15 (more than 15 percentage points above the corresponding Treasury rate) to eliminate cases of likely gross mismeasurement.

The RISK-RATING on the loan is assigned by the bank and reported on the STBL, with 1 indicating "minimal" risk, 2 indicating "low" risk, 3 indicating "moderate" risk, 4 indicating "acceptable" risk, and 5 indicating that the loan is special mention or a classified asset (usually part of a workout arrangement). The STBL instructions relate the rating of 1 with AA-rated corporate bonds and the rating of 2 with BBB-rated corporate bonds, but it is difficult to provide a bond rating equivalent for the other STBL risk ratings.

\subsection{Comparisons of SME lending by banking entity size class}

We first show how the means of the variables differ by size class and discuss some of the potential reasons for the differences. We then conduct more formal econometric tests of some of the differences using regression methods.

\subsubsection{Means by entity size class}

Table 2 shows the means and numbers of observations for the variables by entity size class. Almost all of the banks with Call Reports (8554 of 8562) report information needed to compute the SME-RATIO variables. ${ }^{7}$ Many fewer respond to the STBL and give their contract terms on the STBL, and some of these

\footnotetext{
${ }^{7}$ The other 8 banks report some Call Report information, but do not provide sufficient data on small commercial loan quantities.
} 
respondents do not give risk ratings. As discussed above, the STBL oversamples the largest banks, and so includes more of the banks in entities likely to adopt A-IRB, and includes almost all of the large banks in those entities. As shown, most of the banks with SME-RATIO data from the Call Report are in the Community size class, whereas most of the loans with contract terms and with risk ratings are in the Top 20 size class.

Although there appear to be adequate numbers of observations in all size classes for all variables to perform the empirical analyses, a note of caution is in order before proceeding. For the smaller entity size classes, particularly the Community size class, the sample sizes are quite small relative to the population for the loan contract terms and risk ratings. As shown in Table 2, only 94 of 7520 banks in the Community size class, about $1.25 \%$ of the population, have STBL data available on the loan contract terms, and this shrinks to 74 or less than $1 \%$ of the population for the risk ratings. Although the STBL is designed to create representative samples of banks in all size classes, these sample sizes merit additional caution regarding potential problems of unrepresentative samples in interpreting our loan contract terms and risk rating results for banks in the Community size class.

In Table 2, the means for the SME-RATIO are weighted by GTA, so that they represent the proportion of GTA that is invested in SME loans for each size class. Without the weighting, the mean for each size class would be dominated by the smallest banks in the respective classes, which typically outnumber the larger banks, but have relatively few of the assets (particularly for the large size classes). The means of the loan contract terms and risk ratings do not require such weighting, as they are already dominated by the large banks because each large bank generally reports more loans each quarter than small banks and because of the oversampling of large banks.

Consistent with the research literature, the weighted-average SME-RATIO figures shown in Table 2 indicate a steep decline in SME-RATIO by entity size class. In particular, the ratio for likely A-IRB banks in the Top 20 size class of $2.14 \%$ is dramatically lower than the $8.05 \%$ for Community banks. The weighted average SME-RATIO for Top 20 banks also differs somewhat from the other size classes of large banking entities, with a 5.15\% ratio for Other Large, and 3.38\% for Entities 21-50. However, as discussed above, the use of the weighted-average SME-RATIO alone is not convincing evidence of a strong comparative disadvantage for large banking organizations in relationship lending to SMEs or SME lending altogether 
because of the use of assets in the denominator. In fact, large banking organizations make a substantial proportion of the SME loans in the nation, despite their relatively low SME-RATIOS. As shown in the last row of Table 2, based on the June 2002 Call Report, banks in the Top 20, Entities 21-50, Other Large, and Community size classes accounted for $34.19 \%, 11.79 \%, 22.16 \%$, and $31.86 \%$ of total bank SME loans, respectively.

In the remainder of the empirical analysis, we focus on SME contract terms and risk ratings, which may give more definitive evidence on the issue of the comparative advantages or disadvantages of banks in the different entity size classes in different types of SME lending. Turning first to PREMIUM, all of the large entity size classes have substantially lower average PREMIUM values than Community banks, a difference of over 100 basis points in all cases. Specifically, Community banks have average PREMIUM of $5.10 \%$ versus between $3.54 \%$ and $3.92 \%$ for the three large entity size classes. This evidence is consistent with the literature and with the hypothesis that large banking organizations tend to specialize in transactions loans which tend to be less risky, less costly, and/or involve less market power over the borrowers on average, while community banks tend to specialize in relationship loans - which tend to be more risky, more costly, and/or involve more market power over the borrowers on average. In addition, there does not appear to be any strong systematic difference in average PREMIUM between banks in the Top 20 size class and the two other large size classes, suggesting that these banks may make similar loans.

With respect to the other loan contract terms, COLLATERAL is pledged somewhat less frequently on SME loans for the largest two banking entity size classes, $73.03 \%$ and $77.53 \%$, than for the smallest two size classes, $81.31 \%$ and $87.50 \%$. These differences are smaller than were found in prior research, likely due at least in part to the secular increase in the use of collateral in bank lending. ${ }^{8}$

The differences with regard to DURATION and COMMITMENT across entity size classes provide support for the hypothesis that Top 20 banks make different types of loans than community banks. However, it is not possible to use these variables to make important inferences about the risks of the loans because the prior literature is ambiguous about the associations between these contract terms and loan risk. ${ }^{9}$ Finally, the

\footnotetext{
${ }^{8}$ In the STBL sample, the proportion of loans with collateral pledged rose from about $50 \%$ in the early 1980 s to about $80 \%$ in the early 2000 s.

${ }^{9}$ The theoretical literature on debt maturity - which is very close to loan DURATION - yields ambiguous predictions about the effects of risk (e.g., Flannery 1986, Diamond 1991), and the empirical literature is ambiguous as well (see
} 
CREDIT SIZE of SME loans increases substantially with banking organization size, consistent with legal lending limits, problems of diversification, and sheer size for community banks, and with the hypothesis that large banks tend to make larger transactions loans, and community banks tend to make smaller relationship loans. $^{10}$

Turning to the RISK-RATING differences, a seemingly counterintuitive finding is that banks in the Community size class tend to report their SME loans as being much safer on average than banks in the large entity size classes. For example, banks in the Community size class report that $26.71 \%$ of their SME loans are in the safest two risk categories 1and 2, roughly equivalent with AA and BBB corporate bond ratings, whereas banks in the Top 20 banking organizations report that only 3.59\% of their SME loans are in these two safest risk ratings. This is counterintuitive because 1) based on the literature reviewed above, it is expected that community banks tend to specialize in relatively risky relationship loans to informationally opaque SMEs, 2) our data showing much higher average PREMIUMs and somewhat higher COLLATERAL incidence on this same set of loans are consistent with the expectations from the literature, and 3) it seems unlikely that a substantial proportion of the SME loans made by banks of any size would have risks comparable to the public debt of publicly rated corporations. To our knowledge, this issue has not been previously explored in the research literature.

One potential explanation of this seemingly counterintuitive result is that community banks make much safer SME loans than large banking organizations. We view this explanation as rather unlikely, given the arguments and evidence in the literature that community banks tend to specialize in relatively risky relationship lending. The much higher PREMIUM for Community banks are also likely to reflect higher risk, although they may also incorporate higher operating costs or market power. Prior evidence suggests that the PREMIUM may be a better indicator of loan risk than the RISK-RATING. One study found that RISKRATING did not add much information to loan interest rates in predicting future nonperforming loans, although the study did find RISK-RATING helped predict future CAMEL downgrades (Morgan and Ashcraft 2003).

Berger, Espinosa-Vega, Frame, and Miller 2003). The literature on loan commitments similarly found no strong association between COMMITMENT and loan risk (see Berger and Udell 1998 for a review).

${ }^{10}$ An exception to the "rule" that transactions SME loans tend to be large is the case of small business credit scoring, which is primarily on SME loans below $\$ 100,000$ or below $\$ 250,000$, as discussed below. 
A second potential explanation is that community banks and large banks may have risk management systems that assign risks in different ways or employ different standards for risk ratings. To the extent that very large banking organizations and community banks evaluate risks differently, it would support the arguments that different sizes of banking organizations use different lending technologies. In particular, SME loans may be systematically evaluated as riskier using transactions lending technologies than they would be using relationship lending technology.

A third potential explanation is that community banks and large banking organizations may have different ways of translating their internal risk ratings into the STBL risk ratings. On the one hand, large organizations may report that almost none of their SME loans are roughly equivalent to AA and BBB corporate bond ratings because SMEs virtually never issue corporate bonds. The large institutions may reserve RISK-RATING1 and RISK-RATING2 primarily for their loans to publicly rated corporations and generally rank their SME loans as being of unrated quality. On the other hand, community banks, which typically have relatively few loans to rated corporations, may view the STBL instructions differently and assign risk ratings of 1 and 2 to their safest business customers. We view this potential explanation as most likely, based on the argument above that it seems unlikely that banks of any size would have substantial proportions of their SME loans with risks comparable to the public debt of rated corporations.

A second notable finding from the RISK-RATING data is that the banks in the top two size classes report unexpectedly high portions of their newly issued SME loans in the highest risk category. As shown in the table, the Top 20 and Entities 21-50 report about 8.7\% and 13.1\% of their SME loans as RISK-RATING5, indicating special mention or classified asset. It would be expected that very few loans would be in this category at the time of issue, except if they are to existing borrowers with other problem loans at the same bank. As noted above, a minority of transactions credits - particularly asset-based loans and perhaps some loans issued using small business credit scoring - may be quite risky. One possible explanation of the unexpectedly high proportions of RISK-RATING5 loans for Top 50 entities may be that some of the banks put some of their new credits for which there are high probabilities of default in this category, perhaps interpreting a rating of 5 as appropriate for the lowest pass category. ${ }^{11}$

\footnotetext{
${ }^{11}$ A preliminary examination of STBL data from 2003 is consistent with the two unexpected findings here that banks in the Community size class report relatively high proportions of their SME loans as RISK-RATING1 or RISK-RATING2, and that banks in the Top 50 size classes report relatively high proportions as RISK-RATING5.
} 
As an additional check on the reported risk ratings, we examine the average PREMIUM for the 5 different risk ratings for each of the 4 entity size classes. If PREMIUM reflects loan risk and RISK-RATING accurately measures loan risk, then we expect to find that that higher risk ratings are associated with higher average PREMIUM (unless loan risk were strongly negatively associated with operating costs, market power, or other important factors in setting rates). The findings (not shown in tables) are generally consistent with the expectation of a positive relationship between premiums and reported loan risk, although there are some exceptions. We focus on RISK-RATING1 or RISK-RATING2 versus the higher risk ratings and RISKRATING5 versus the lower risk ratings because these are the ratings for which the STBL instructions appear to provide the clearest benchmarks that may or may not be followed, i.e., roughly equivalent to the risk of a publicly-rated corporate bond, or to a special mention/classified asset, respectively. For banks in the Community size class, PREMIUM shows the expected relationships, with the mean PREMIUMS being the lowest for risk ratings 1 and 2 (0.04154 and 0.04484), higher for risk ratings 3 and 4 (0.05264 and 0.05291), and still higher for risk rating 5 (0.05923). Similar patterns also hold for the Other Large and Top 20 size classes. However, the expected relationship does not entirely hold for Entities 21-50, with mean PREMIUMS for risk ratings 1 and $2(0.02854$ and 0.03885$)$ that are not always lower than those for risk ratings 3 and 4 (0.03577 and 0.03638), and then a relatively low mean PREMIUM for risk rating 5 (0.03219). Overall, the data suggest interpreting results based on the reported risk ratings only with great caution.

\subsubsection{Tests of differences by entity size class using regression methods}

We next conduct more formal econometric tests of some of the differences in loan contract terms and risk ratings using regression models that control for other factors. The comparisons of individual loan contract terms without controlling for the other contract terms and the risk ratings shown thus far may be misleading. The contract terms are expected to be interrelated and to depend on the bank's evaluation of borrower risk. For example, a bank might be expected to charge a lower PREMIUM to the same borrower for the same purpose if the loan is of shorter DURATION because shorter duration reduces credit risk. The contract terms may also provide additional signals about the loan risk (e.g., COLLATERAL loans are generally riskier). Comparisons of RISK-RATING values without controlling for some of the contract terms may also be misleading for the same reasons. The regression models help address these issues. However, because the contract terms and risk ratings may all be jointly endogenous and we do not have instruments for 
these variables, we run the regressions with and without the other contract terms and risk ratings on the righthand-side.

Tables 3, 4, and 5 show the regressions for PREMIUM, COLLATERAL, and RISK-RATING, respectively, using all of the available SME loan observations from the STBL (we view the other contract terms as less important and do not include them as dependent variables). Three PREMIUM regressions are shown in Table 3. The first has just the intercept and the banking entity size class dummies, OTHER LARGE, ENTITIES 21-50, and TOP 20, with COMMUNITY excluded as the base case. The second regression adds the other loan contract terms, COLLATERAL, COMMITMENT, DURATION, and the natural $\log$ of CREDIT SIZE. The third regression also includes dummies for the risk ratings, RISKRATING2, RISK-RATING3, RISK-RATING4, and RISK-RATING5, with RISK-RATING1 excluded as the base case.

The results shown in Table 3 are consistent with the differences reported in Table 2. In all cases, the coefficients on the size dummies are statistically significant, negative, and more than 100 basis points in magnitude. The Top 20 and other large banks are measured to have lower PREMIUMs than community banks with no controls, with controls for other contract terms, and with controls for risk ratings, and the difference is fairly large. Again, the data are consistent with the hypothesis that large banks tend to make transactions loans that are associated with less risk, less cost, and less market power over the borrowers than the relationship loans that are made by community banks. It is possible that part of the average PREMIUM differences of over 100 basis points between large banking organizations and community banks compensates for average higher fees, compensating balances, or net revenues earned elsewhere in the bank-borrower relationships by large banking organizations, but it seems unlikely that any systematic differences by entity size in these factors could explain such large magnitudes. ${ }^{12}$

We also test for the statistical significance of the differences between the Top 20 banks and banks in other large banking organizations. The t-statistics for testing the differences between the coefficients on the intermediate size classes and TOP 20 are shown in the final column of Table 3. The OTHER LARGE

\footnotetext{
${ }^{12}$ The adjusted $\mathrm{R}^{2}$ rises considerably from about 0.04 to about 0.25 when the other contract terms are added, although the risk ratings add essentially no additional explanation of the variance in PREMIUM. As shown in Table 3, all of the contract term and risk rating variables are statistically significant both individually and in joint groupings.
} 
coefficients are within 10 basis points of and are not statistically significantly different from the TOP 20 coefficients. The ENTITIES 21-50 coefficients are about 30 basis points lower than and are statistically significantly different from the TOP 20 coefficients. The 30 basis point difference between the largest size classes might reflect differences in intensity of use of the different transactions lending technologies financial statement lending, asset-based lending, and small business credit scoring. As noted above, assetbased lending and/or credit scoring may be associated with higher premiums than financial statement lending. These differences among the three large size classes are not as strong and consistent as the differences between the three large sizes and the Community size class, and in our view do not demonstrate a clear separation among the types of SME loans made by the different large size classes.

Table 4 shows three analogous regressions for COLLATERAL. One difference in specification is the use of the logit functional form because COLLATERAL is a $0-1$ dummy dependent variable. Another difference is that we do not include PREMIUM as a regressor, whereas we used COLLATERAL as a regressor in the PREMIUM regressions in Table 3. The maintained assumption is that of a recursive model, in which the loan rate is set last, after the collateral decision is made and the other contract terms are in place. The results are again statistically significant and consistent with the differences in means shown in Table 2 above. The largest two entity size classes have statistically significantly lower probability of COLLATERAL than the smallest two classes. The difference between the largest two size classes is also statistically significant, but smaller. As noted above, the differences in collateral incidence found here are all small relative to the findings in prior research, likely due at least in part to the secular increase in the use of collateral. ${ }^{13}$

Table 5 shows the RISK-RATING regressions with and without the contract terms (again PREMIUM is not included as a regressor under the assumption of recursiveness). The regressions are run as ordered logits, because RISK-RATING is an ordered, 5-value indicator variable. The results are again statistically significant and consistent with the differences in means shown in Table 2 above. Banks in all the large entity size classes report their SME loans as riskier than do community banks, consistent with the hypotheses that community banks and large banks assign risks differently or that the different organizations translate their

\footnotetext{
${ }^{13}$ As shown in Table 4, all of the contract term and risk rating variables are statistically significant both individually and in joint groupings.
} 
internal risk ratings into the STBL risk ratings very differently. Among the large bank size classes, ENTITIES 21-50 show the highest reported risk ratings. ${ }^{14}$

\subsection{Robustness checks}

We conduct a number of robustness checks on our empirical results, which we describe briefly here. First, we try comparing loan contract terms and risk ratings for loans drawn under commitment only, i.e., for COMMITMENT $=1$ only. This makes for a more homogenous set of loans to compare, given that most commitment loans are lines of credit, which are often used for working capital purposes. Prior research has found significantly different pricing results for SME loans when the sample is limited to loans drawn under lines of credit (e.g., Berger and Udell 1995). Table 6 shows a comparison of loan contact and risk rating means for COMMITMENT $=1$ loans only. As shown, our main results are robust to the exclusive use of these loans. Relative to community banks, the average PREMIUM is again more than 100 basis points lower for all of the large bank entity classes, the average incidence of COLLATERAL is again slightly lower for the largest two size classes, DURATION is considerably lower for the Top 20 banking organizations, and CREDIT SIZE is larger for the three large entity size classes, particularly for the top two classes. The proportion of loans classified as corporate grade is also much lower for all the large entity size classes than for community banks. These differences are reinforced by regression analysis (not shown).

Second, we check the extent to which the main results on PREMIUM may derive from outliers or mismeasurement. As noted above, we always delete observations for which measured PREMIUM was less than -0.01 or greater than 0.15 . We also try rerunning the PREMIUM regressions with more truncation of outliers. Specifically, we try eliminating observations with measured PREMIUM less than $-0.01,0.00,0.01$, or 0.02 , and those with measured PREMIUM above 0.10 or 0.15 , and all the combinations of these lower and upper bounds. Every coefficient on OTHER LARGE, ENTITIES 21-50, and TOP 20 in all of these regressions is statistically significant, negative, and large in magnitude. In only one case in which we used the most restrictive truncation - leaving only observations of PREMIUM between 0.02 and 0.10 - does a coefficient fall below 100 basis points in magnitude to 95 basis points (not shown). This check suggests the main PREMIUM results are not driven by grossly mismeasured outliers.

Third, we try re-estimating the PREMIUM regressions in various ways to determine if the main

\footnotetext{
${ }^{14}$ As shown in Table 5, all of the contract term variables are statistically significant both individually and jointly.
} 
results are driven by loans with particular risk ratings. In one case, we rerun the regressions shown in Table 3 with all of the RISK-RATING5 loans deleted. In each of these regressions, the coefficients on the size dummies remain statistically significant, negative, and more than 100 basis points in magnitude (not shown). We also rerun the PREMIUM regressions for the individual risk rating categories, except that we group RISK-RATING1 and RISK-RATING2 together because of the substantially fewer numbers of observations of these ratings. That is, we run the regressions for four separate subsamples - RISK-RATING1 or RISKRATING2, RISK-RATING3 alone, RISK-RATING4 alone, and RISK-RATING5 alone. In each of these regressions, the coefficients on the size dummies remain statistically significant and negative. The magnitudes continue to exceed 100 basis points in all cases except the ENTITIES 21-50 dummies in the regressions using data for RISK-RATING1 or RISK-RATING2, in which the coefficients are about -64 and 79 basis points, depending on whether the other contract terms are included (not shown). Thus, the main results do not appear to be driven by loans with any particular risk ratings.

Fourth, we check the extent to which the main results are robust across various credit size classes of SME loans. As discussed above, we separate the SME loan data into credit size classes of $\leq \$ 100 \mathrm{~K}, \$ 100 \mathrm{~K}$ $\$ 250 \mathrm{~K}$, and $\$ 250 \mathrm{~K}-\$ 1 \mathrm{M}$ to see if there are differences in the comparative advantages of large and small banking organizations in the use of transactions and relationship lending technologies, given that these technologies may function differently on different-sized credits (e.g., small business credit scoring). Table 7 shows a comparison of SME-RATIO, loan contract, and risk rating means by banking entity size class. As shown, our main results are robust across the credit size classes. For all three credit size classes, the SMERATIO is declining in bank entity size class, with much smaller lending ratios for Top 20 banks. As well, relative to community banks, the average PREMIUM is again more than 100 basis points lower for all of the large bank entity classes, DURATION is considerably lower for the Top 20 banking organizations, and CREDIT SIZE is larger for the three large entity size classes, particularly for Top 20 banks. The proportions of loans classified as corporate grade is also much lower for all the large entity size classes than for community banks. The only differences that are not fully robust across all the size classes are the differences in COMMITMENT status, and to some degree, COLLATERAL status. Again, the differences shown in Table 7 are reinforced by regression analysis (not shown).

For our final robustness checks, we look more closely at the SME loans made by individual banks. 
As discussed above, although banks in the Top 20 as a whole have very different average lending characteristics from community banks, there could be a significant minority of the Top 20 banks with similar SME loan portfolios to community banks. A large number of such banks controlling a substantial proportion of the assets and SME loans of the Top 20 entities could potentially pose a significant competitive threat to community banks in the SME lending market. Similarly, if a significant minority of small banks that are typically labeled as community banks have SME portfolios that are more like large banks, then may be significant competitive effects on this subgroup of small banks that would not otherwise be apparent from the literature or full-sample statistics.

Table 8 shows Bank GTA, Entity GTA, and SME-RATIO for all SME loans (i.e., CREDIT SIZE $\leq$ $\$ 1 M)$ in each of the 130 individual banks in the Top 20 entity size class (recall that many of the Top 20 entities are BHCs that own multiple banks). These are shown in descending order by SME-RATIO to see if a significant minority of these banks have SME lending ratios similar to community banks. As shown, only 10 of the 130 banks (owned by 5 of the Top 20 entities) have SME-RATIOs as large as the average ratio for community banks of 0.0805 shown in Table 2 above. Only 3 of these banks have bank GTA above $\$ 1 B$, and the largest is just over $\$ 6 \mathrm{~B}$. Thus, these data suggest that as of 2002 , only a very small minority of banks with a very small minority of assets of the entities that are likely to adopt A-IRB are in banks that make SME loans in similar proportions to typical community banks.

Table 9 shows the average PREMIUM for all SME loans (i.e., CREDIT SIZE $\leq \$ 1 M$ ) in each of the 35 individual banks in the Top 20 entity size class with loan contract information available from the STBL (recall that only a minority of banks respond to the STBL). ${ }^{15}$ These are shown in descending order by average PREMIUM to see how many of these banks tend to charge PREMIUM similar to community banks. As shown, despite the large variation across the 35 banks, none of them have average PREMIUM as large as the average for community banks of 0.0510 shown in Table 2 above, and only one bank is within about 85 basis points of the community bank mean. Although the one bank with mean PREMIUM close to the mean for community banks is a large institution, we note that its SME-RATIO (not shown) is quite small, even less than the average for Top 20 banks of 0.0214 shown in Table 2. These data suggest that as of 2002, only a

\footnotetext{
${ }^{15}$ We cannot show the Bank GTA or Entity GTA for these individual institutions to protect the confidentiality of the STBL respondents.
} 
very small minority of assets of the banks that are likely to adopt A-IRB are in banks with mean PREMIUM similar to those typical of community banks. As a caveat, we cannot rule out the possibility that some of these banks in large organizations tend to specialize in relationship loans but have low premiums due to low risk, low operating costs, and/or low market power. As an additional caveat, we again note that the STBL tends to sample the larger banks within the Top 20 size class, so the 35 banks shown may not be fully representative of all 130 banks in this size class. Despite these caveats, the data are consistent with the regression results and with the research literature that suggest that banks in these large organizations tend to focus on transactions lending.

Table 10 shows average PREMIUM for all SME loans in each of the 94 banks in the Community size class with loan contract information available from the STBL. These are shown in descending order by mean PREMIUM to see how many of these banks have mean PREMIUM that overlap with the Top 20 banks. As shown, these banks have a wide variation in mean PREMIUM, ranging from about $\%$ to over $8 \%$. Of the 94 banks, 73 have mean PREMIUM above 0.0425, the second-highest mean PREMIUM for the Top 20 banks. Thus, the majority of the banks in the Community size class have virtually no overlap with the Top 20 banks. The other 21 banks in the Community size class have mean premiums that do overlap with those of the Top 20 banks. Some of these 21 banks may make the traditional relationship loans of community banks but tend to charge unusually low premiums due to low risk, low operating costs, and/or low market power. Others may be small banks that tend to focus on transactions loans and behave more like large banks than like traditional community banks that tend to focus on relationship loans. The competitive effect of a given change in marginal costs for SME lending by A-IRB banks may be more significant on this last subgroup of small banks, given that some of them may primarily make the same types of transactions loans as the A-IRB banks.

The caution noted above about the very small sample size for Community bank data on loan contract terms relative to the population applies with particularly great force here because we are dealing with a minority of the sample observations and because this is an analysis that has no counterpart in the research literature with which to check consistency. That is, although 21 of 94 sample banks in the Community size class with data available on PREMIUMs overlap with the Top 20 banks, the fact that these sample observations are such small proportions of the population in a single time period calls attention to the 
potential problem that they may not represent the population. As well, unlike the regression analyses - which essentially replicate an established body of research literature with different data sets, variables, time periods, and methodologies - our analysis of individual banks is unprecedented, and so should be viewed with additional caution. In our view, the overlap finding here raises the possibility that a significant minority of the population of small banks may tend to focus on transactions loans and behave more like large banks than like traditional community banks, but does not provide strong evidence of it. Additional future research with more extensive data would be needed to determine whether a strong case may or may not be made on this issue.

To sum up, the empirical findings in this section generally reinforce those in the literature regarding the different types of SME loans made by likely A-IRB banks and community banks. The findings suggest relatively small competitive effects on the majority of community banks in SME lending markets from A-IRB adoption, unless the marginal cost benefits to A-IRB banks for the types of SME loans made by community banks are relatively large. A possible exception may be a significant minority of the population of small banks that may focus on transactions loans and behave more like large banks than like traditional community banks, but the evidence on this point is not strongly established and is highly uncertain. In addition, although some differences in loan characteristics do exist, the empirical findings do not demonstrate a clear separation among the types of loans made by likely A-IRB banks and other large banking organizations, other than potentially different mixes among the transactions loans categories. This leaves open the possibility of significant competitive effects on many of these other large institutions from relatively modest marginal cost effects of A-IRB.

\section{The marginal cost effects of A-IRB on SME credits}

In this section, we briefly examine how the adoption of A-IRB may affect the marginal costs of $\$ 1$ of SME lending (MC) for the adopting banks. As will become clear, accurate estimation of MC is not possible, but we obtain a rough estimate of an upper bound to the magnitude for the average A-IRB bank. It is not intended to apply to every A-IRB bank or every loan by these banks, but to provide an order of magnitude to determine whether, in general, the incentives might be sufficient to result in significant effects in SME lending markets on the competitive positions of community banks and other banks in large organizations that do not adopt A-IRB. 
The effects of the adoption of A-IRB on MC depend first on how A-IRB changes required capital. As noted above, the required capital for an SME loan under A-IRB may depend on a number of factors, including the PD and LGD assigned by the bank, the classification of the loan as retail or corporate, and the sales of the borrower. For some risky loans with high PD and LGD, the required capital would increase, and for others, the required capital would decrease. For our purposes, we use an estimated average effect from a survey of 22 large U.S. institutions in the Quantitative Impact Study 3 (QIS3, Basel Committee on Bank Supervision 2002) that may represent organizations that will be required to adopt A-IRB or may opt into A-IRB. Seventeen of the 22 institutions provided estimates of the effect on their SME portfolios. The weightedaverage estimate from these 17 institutions is a $33 \%$ reduction in required capital on SME loans from the $100 \%$ risk weight category of Basel I. This would reduce the required Tier 1 and Total capital ratios on these loans from $4 \%$ and $8 \%$, respectively, to $2.68 \%(.67 \times 4 \%)$ and $5.36 \%(.67 \times 8 \%)$, respectively, on average.

We emphasize that the $33 \%$ reduction in required capital to be held against SME loans is a very rough estimate based on a survey of firms that may not have their final risk models in place, and is based on current portfolios of SME loans rather than future portfolios that may have different risk characteristics due to the incentive effects of A-IRB and other factors. It should also be emphasized that the weighted average may not reflect the SME portfolios of individual banking organizations - some may have much higher or lower changes in capital requirements. For example, several institutions in the QIS3 sample reported estimated reductions of over $60 \%$, with a maximum of a $69 \%$ reduction. At the other end of the distribution, several institutions gave estimates of no reduction or a slight increase of up to $4 \%$ in required capital for SME credits as result of A-IRB adoption. Moreover, these findings may be confirmed or altered by the QIS4 study in the second half of 2004. Because of the variation and uncertainty, we will discuss sensitivity to changing the $33 \%$ estimate below.

The $33 \%$ estimate is for all of the institutions' SME loans, and includes the PD, LGD, retail, and "carve-out" effects. Some additional rough calculations suggest that about $40 \%$ of the total reduction may be due to the "carve-out" effects, i.e., the use of lower asset correlations for corporate exposures to firms with sales under $€ 50$ million. This estimate should be considered inexact and subject to all of the same qualifications as the $33 \%$ estimate of the overall reduction. The contribution to the $33 \%$ overall reduction from the relatively favorable treatment for retail exposures could not be separately estimated. However, it is 
likely to be relatively small, given that in the QIS3 survey less than $20 \%$ of the SME credits were classified as retail, and the estimated average measured effect per dollar of retail SME exposures (27\% reduction) was slightly less than for corporate exposures (34\% reduction). Thus, much of the $33 \%$ reduction is likely due to the remaining category - the use of the PDs and LGDs assigned by the banks to the individual SME loans under A-IRB. ${ }^{16,17}$ Again, this breakdown should be considered as very rough.

Even if the change in regulatory minimum capital requirements were known and the market required rates of return on bank equity and debt were known, the MC effect is difficult to estimate. This is because there are factors that would tend to reduce the magnitude of the reduction in $\mathrm{MC}$ and their exact effects are hard to determine.

First, the change in MC depends on how much, if any, of the reduction in required capital the A-IRB banking organizations actually take. There are several reasons to expect that institutions may not reduce their actual capital by the full amount of the reduced requirements. An institution's equilibrium capital ratios are determined by market factors as well as by regulatory requirements in a trade-off among various capital market imperfections. Research evidence and market participants also indicate that banking organizations generally hold buffers of capital above the current market and regulatory requirements to allow them to exploit unexpected future profitable investment opportunities and to cushion the effects of unexpected future negative shocks. The buffers may be substantial if the penalties for falling below the minimums are very costly and if the transactions costs of raising capital quickly are very high. ${ }^{18}$ As well, bank supervisors may stand in the way of capital reductions with conventional supervisory pressure if they believe the bank would be unsafe or unsound after such reductions. Supervisors in the U.S. also impose leverage requirements, or minimum capital ratios against unweighted assets, as well as prompt corrective actions (PCA) that depend on

\footnotetext{
${ }^{16}$ To see if the reductions in capital requirements estimated by the QIS3 banks were related to SME loan risk in the predicted fashion, we examined the differences in mean PREMIUMs across these organizations. Specifically, of the 17 QIS3 institutions that provided estimates of the effect of A-IRB on their SME portfolios, we were able to match 12 with Top 20 banking organizations with loan contract information available from the STBL. The correlation between the estimated reduction in required capital and the mean PREMIUMs for these 12 organizations was -0.70 (statistically significantly different from 0 at the $5 \%$ level), consistent with the expectation that A-IRB reduces capital requirements more for banks with safer SME credits.

${ }^{17}$ See Repullo and Suárez (2003) for some examples of how the capital requirements may vary with the assumed PD and LGD of different risk exposures. Also, see Saurina and Trucharte (2003) for analysis of the effects of Basel II on SME credit availability in Spain.

${ }^{18}$ See Berger, Herring, and Szego (1995) for a general discussion of market capital 'requirements,' regulatory capital requirements, and buffers above both of these 'requirements.'
} 
various capital ratios. Any potential reduction in capital might violate the banking organization's leverage or PCA requirements or reduce the buffer over these requirements to an undesirable level, eliminating or tempering any actual reductions in capital that might otherwise result from the change in minimum risk-based requirements. All of these factors suggest that it is likely that actual capital reductions would be smaller than any reductions in required capital for A-IRB banks, although we acknowledge the possibility that some banks could choose to reduce capital by more than the change in requirements (i.e., choose smaller buffers).

Second, even if full reductions in actual capital ratios occurred that paralleled the change in minimum regulatory requirements, the change in $\mathrm{MC}$ would likely be tempered by some offsetting effects. The most important of these would likely be an increase in market-required expected rates of return on debt and equity to reflect the increased risk to debt holders and equity holders from the decrease in capital ratios, or the "Modigliani-Miller effect" (Modigliani and Miller 1958). Because of market imperfections, the offset to MC will generally be incomplete, but some offset would be likely to occur in the long run. ${ }^{19}$ In addition, because of agency problems between the management of the banking organization and its external claimholders, part of any reduction in marginal financing costs may be offset by increases in operating costs. For example, prior research suggests that increases in profitability from the exercise of market power are similarly tempered by reduced cost efficiency, presumably because of reduced effort or pursuit of other goals by managers (e.g., Berger and Hannan 1998).

It is not possible to determine how much all of these factors would limit the magnitude of the reduction in $\mathrm{MC}$, so we instead obtain a rough estimate of an upper bound to the magnitude of the MC decline for the average A-IRB bank as a second-best alternative. For this upper bound, we assume that the capital ratios fall by the full amount of the reduction in required capital - i.e., no offset from market factors, no reductions in buffers above the regulatory minimums, no conventional supervisory pressure or Prompt Corrective Actions to prevent the full reduction, no effective leverage requirements or effect of buffers over the leverage requirements. For the upper bound, we also assume no tempering of the change in $\mathrm{MC}$ of the

\footnotetext{
${ }^{19}$ Market imperfections include taxes, costs of financial distress, transactions costs, asymmetric information, and, in banking, regulation. See Berger, Herring, and Szego (1995) for more discussion of the Modigliani-Miller effect for financial institutions. Also see Board and Governors and U.S. Treasury (2000, Appendix C) for a review of empirical evidence that suggests that the market requires higher rates on the subordinated debt of riskier banking organizations, consistent with a significant Modigliani-Miller effect.
} 
reductions in capital ratios - i.e., no Modigliani-Miller effect in which markets require higher expected rates of return to compensate for the increased risks from the reduction in capital ratios, and no agency problems that prevent the external claimholders from capturing the full benefits of the financial gains, rather than the managers.

Under these very strong assumptions, the reduction in $\mathrm{MC}$ is given by:

$\left(r_{1}-r_{D}\right) \times .33 \times .04+\left(r_{2}-r_{D}\right) \times .33 \times .04$

where:

$\mathrm{r}_{1}$ is the required marginal return on Tier 1 capital,

$r_{2}$ is the required marginal return on Tier 2 capital,

$r_{D}$ is the required marginal return on debt that does not count as regulatory capital,

.33 is the reduction in required capital on SME loans.

Thus, we assume that the bank reduces capital by the full amount of the regulatory change, $.33 \times .04$ from Tier 1 capital and the remaining $.33 \times .04$ for the Total capital requirement from Tier 2 capital, and increases its non-regulatory-capital debt, including deposits and short-term borrowings, accordingly. To clarify, required capital may be in the form of equity, certain types of debt, and other financial instruments that are not easily classified as equity or debt, so we refer to debt that does not count as Tier 1 or Tier 2 capital as non-regulatory-capital debt.

Estimates for $\left(r_{1}-r_{D}\right)$ and $\left(r_{2}-r_{D}\right)$ may be obtained in various ways. We choose a method that is straightforward, conservative (to be consistent with our upper-bound assumptions), based on market information (rather than accounting data), and has been used in earlier research.

One of the classic problems in finance is the "equity premium puzzle" in which the average return on corporate equities is about 6 percentage points higher than the average return on corporate debt. We simply apply this premium to both $\left(r_{1}-r_{D}\right)$ and $\left(r_{2}-r_{D}\right)$ in the formula above - i.e., assume that the required marginal returns on both Tier 1 capital and Tier 2 capital are both 6 percentage points higher than the required marginal return on non-regulatory-capital debt. This is conservative in that it assumes that the equity premium applies to the whole $8 \%$ of regulatory capital, even though much of the regulatory capital is debt or other instruments, rather than equity. It has the benefit of being based on market data, rather than accounting data, although qualitatively similar results were found when average returns on equity and average rates paid on long-term 
debt (purchased funds) calculated from accounting data for large banking organizations were used instead. Finally, these are also the exact figures used by Repullo and Suárez (2003) to estimate the effects of Basel II capital requirements. Substituting 0.06 for $\left(r_{1}-r_{D}\right)$ and $\left(r_{2}-r_{D}\right)$ in the formula gives a reduction in $M C$ of 0.001584 , or a decline of about 16 basis points as the upper-bound estimate.

The substitution effect of the decline in MC will generally encourage A-IRB banks to reduce price and/or increase quantity supplied of SME credit. The effect on the competitive position of community banks and other banks in the SME lending market depends on several factors, including the market power of the lending banks, the abilities of the banks to change output, the strength of bank-borrower relationships, the opacity of the borrowers, any proprietary information of the lending banks, the geographic distance between banks and borrowers, the types of SME loans among different banks, the switching costs of borrowers, the elasticity of supply of other market participants, and so forth.

We argue that the key issue that is likely to determine the competitive effect on community banks is the comparative disadvantage of large banking organizations in competing with community banks for relationship credits to informationally opaque SMEs discussed in the literature review in Section 2 and the empirical analysis in Section 3. Although the numbers are not strictly comparable, the 16 basis points estimate of the upper bound to the decline in MC for the average A-IRB bank is small relative to the average differences of over 100 basis points in premiums charged on SME loans between community banks and the very large banking organizations that are likely to adopt A-IRB. Moreover, we note that if the large banking organizations that adopt A-IRB were to compete directly for the SME loans currently made by community banks, the actual cost savings might decline significantly or even turn into a MC increase instead of a decrease. This is because the much higher premiums on SME loans made by community banks presumably reflect higher PD and/or higher LGD, which would raise the capital requirements on these loans.

We next discuss the sensitivity of our estimates to changing the $33 \%$ weighted-average estimate of the reduction in required capital from the QIS3 survey. As noted above, this is a very rough weightedaverage estimate based on a preliminary survey and may not reflect the SME portfolios of individual banking organizations. If we use the range of estimates from the individual U.S. institutions responding to QIS3 of a $69 \%$ reduction to a $4 \%$ increase in required capital in the formula above, this gives a range for the change in 
MC from about a 33 basis point reduction to an increase of about 2 basis points. ${ }^{20}$

It seems most likely that the $33 \%$ reduction in required capital and 16 basis points upper bound for the marginal cost effects are overstatements, at least for the types of SME credits made by most of the community banks. If the A-IRB banks were to substitute into the relationship credits to opaque SMEs in which most community banks now specialize, the required capital reduction and marginal cost savings may diminish significantly or turn into required capital and marginal cost increases. Presumably, much of the reason why community banks charge premiums of more than 100 basis points higher on average than large banks on SME loans is that these loans tend to have higher PD and/or higher LGD, which would raise the capital requirements and marginal cost of these loans under A-IRB. Still, these arguments may not necessarily apply to all banks in the Community size class. As noted, a minority of small banks have mean premiums similar to those of the Top 20 banks, and may tend to focus on relatively safe transactions loans and behave more like large banks than like traditional community banks. The adoption of Basel II may have substantial competitive effects at such banks.

We also cannot rule out the possibility of a significant adverse competitive effect in the SME credit market on other large banking organizations that do not adopt A-IRB. As shown in Section 3 above, banks in the Top 20 entities and banks in Entities 21-50 appear to make similar types of SME loans, so relatively small reductions in MC may have significant competitive effects on banks in Entities 21-50 in the SME credit market.

Although it is not possible to quantify further these competitive effects, there are some potential mitigating factors. First, the decline in MC from the adoption of A-IRB would not occur on all SME loans issued by large banking organizations. As already discussed, for high-risk SME loans with high PD and/or LGD, the A-IRB banks may have very little reduction in $\mathrm{MC}$ on some credits and increased $\mathrm{MC}$ on other credits. Recall that some of the QIS3 sample banks estimated no overall reduction or a slight increase in required capital for their SME portfolios as a whole as result of A-IRB adoption. Thus, the competitive advantage for A-IRB banks may primarily occur on relatively safe SME credits, with non-A-IRB banks possibly having a competitive advantage on some of the riskier SME credits. To some extent, the non-A-IRB

${ }^{20}$ In the unrealistically extreme case of a bank with SME loans with no risk - i.e., with a zero PD and/or zero LGD on all of its SME loans - the reduction in required capital would be $100 \%$, which would yield a marginal cost effect of 48 basis points (approximately three times the upper bound for a 33\% reduction). 
banks may also substitute into riskier SME credits, increasing market share and adversely affecting the competitive position of A-IRB banks. ${ }^{21}$

Second, as discussed above, the substitution effect for a given change in MC depends on a number of factors that affect the ability of one bank to compete for the SME loan customers of other banks. If the SME loans made by large banking organizations were nearly pure, transparent commodities that could be bought and sold in secondary markets without any bank market power, relationships, or proprietary information, and if distance effects, switching costs, etc., were very minor, then a very small change in MC might have a very significant adverse competitive effect on large banking organizations that do not adopt A-IRB. However, even for the transactions loans to relatively transparent SMEs made by large banking organizations, there is very little in the way of a secondary market, and many of the credits likely involve some market power, relationships, proprietary information, opacity, etc., that would likely mitigate the competitive effects of a given change in MC. An alternative method through which the substitution effect could operate is to encourage A-IRB banks to increase their SME credit market shares by acquiring non-A-IRB banks for the purpose of taking over their SME loan portfolios at lower cost. Given the expenses of acquisition and integration and the fact that SME credits are usually only a small part of the target institution's portfolio, this would not likely occur unless an A-IRB bank were close to the margin of making the acquisition for other reasons.

Third, the substitution effect may be blunted in some cases in which large banking organizations tend to specialize in different types of transactions loans. As discussed above, there is about a 30 basis point difference in mean premiums between banks in the Top 20 and Entities 21-50 entity size classes that may reflect differences in the intensity of use among the three different transactions lending technologies financial statement lending, asset-based lending, and small business credit scoring. The substitution effect may be limited, for example, if an A-IRB bank specializing in financial statement loans attempts to take market share from a non-A-IRB bank that specializes in asset-based lending.

\section{Conclusions}

The analyses in this paper suggest two main conclusions. First, the substitution effect of a decline in

\footnotetext{
${ }^{21}$ To the extent that non-A-IRB banks take on these riskier credits, market forces may require these banks to incur the costs of raising additional equity capital and/or to pay higher risk premiums on their uninsured debt.
} 
marginal costs of SME lending by banking organizations that adopt the A-IRB approach of Basel II is likely to have only a relatively minor competitive effect on the majority of community banks in the SME lending market. Although a marginal cost decline is likely to encourage A-IRB banks to reduce price and/or increase quantity of SME lending, reducing the prices received by and/or market shares of community banks, the three analyses here all suggest that this substitution effect is likely to be rather modest in most cases. Our review of the SME lending research literature and our investigation of recent U.S. SME lending data both suggest that the very large banking organizations that are likely to adopt A-IRB tend to make very different types of SME loans to different types of borrowers than community banks because of their different comparative advantages. For example, a very robust result in the recent data is that the very large banking organizations charge average premiums on SME loans that are more than 100 basis points lower than those charged by banks in small organizations that are typically classified as community banks. Our analysis of the marginal costs yields a rough estimate for the upper bound of the marginal cost decline per \$1 of SME loans for the average A-IRB bank of about 16 basis points, which is likely to be too small in most cases to overcome the comparative advantages of community banks in relationship lending. The 16 basis points is likely to be an overstatement in most cases because it is based on the assumptions that 1) capital ratios fall by the full amount of the reduction in required capital with no offset from market or supervisory pressures, and 2) the change in marginal cost is not tempered by markets requiring higher rates of return for the increased leverage risk (Modigliani-Miller effect) or managers expropriating any of the benefits due to agency problems. We use the rough upper bound as a second-best alternative because the effects of these mitigating factors are too difficult to estimate. We also note that the 16 basis points estimate is particularly likely to be an overstatement for the types of SME loans that most community banks tend to make. However, a possible exception to these arguments may be a subset of small banks that may focus on relatively safe transactions loans and behave more like large banks in their SME lending than like traditional community banks. One of our robustness checks raises the possibility that a significant minority of the population of small banks may tend to focus on transactions loans, does not provide strong evidence of it and is highly uncertain due to data limitations. Additional future research with more extensive data would be needed to determine whether a strong case may or may not be made on this issue.

Second, our analysis suggests the possibility that the implementation of Basel II may significantly 
adversely affect the competitive position in the SME credit market of large banking organizations that do not adopt A-IRB. Our analysis of recent U.S. data does not suggest any strong comparative advantages or disadvantages in SME lending for the very large banking organizations that are likely to adopt A-IRB relative to other large banking organizations. Both types of large institutions appear to make transactions loans based on hard information to relatively transparent SME borrowers, although the data suggest there may be somewhat different mixes among the types of transactions loans made (e.g. loans based primarily on financial statement data versus those primarily based on collateral or credit scores). This leaves open the possibility of significant competitive effects from the upper-bound estimate of a reduction in marginal costs of about 16 basis points for the average A-IRB bank. The competitive effects are likely to be greater on relatively safe SME credits, given that A-IRB gives more favorable treatment to SME loans with lower PDs and LGDs, and may be limited or reversed on riskier credits with higher PDs or LGDs. The competitive effects on large organizations that do not adopt A-IRB may also be mitigated by factors that reduce the degree to which one bank can substitute for another, including market power, bank-borrower relationships, opacity, proprietary information, distance effects, switching costs, and the lack of a significant secondary market for SME credits. As well, gaining market share though acquisitions of non-A-IRB banks is likely to be too expensive if it is solely for the purpose of taking over SME loan portfolios to reduce capital costs. As well, the substitution effect may be blunted in some cases in which large banking organizations tend to specialize in different types of transactions loans. However, the degree of substitutability may increase in the future if small business credit scoring or other transactions lending technologies become more prevalent or efficient and/or a liquid secondary market for these credits develops, making SME credits closer to pure commodities and allowing AIRB banks to exploit regulatory capital-based cost advantages by making or holding SME credits from across the country. 


\section{$\underline{\text { References }}$}

Avery, Robert B., and Katherine A. Samolyk. 2004. "Bank Consolidation and the Provision of Banking Services: Small Commercial Loans,” Journal of Financial Services Research 25.

Basel Committee on Bank Supervision. 2002. Quantitative Impact Statement 3. http://www.bis.org/bcbs/qis/qis3.htm.

Berger, Allen N., Seth D. Bonime, Lawrence G. Goldberg, and Lawrence J. White. 2004. "The Dynamics of Market Entry: The Effects of Mergers and Acquisitions on Entry in the Banking Industry." Journal of Business 77.

Berger, Allen N., Marco Espinosa-Vega, W. Scott Frame, and Nathan H. Miller. 2003. "Debt Maturity, Risk, and Asymmetric Information." Federal Reserve Board working paper.

Berger, Allen N., W. Scott Frame, and Nathan H. Miller. forthcoming. "Credit scoring and the availability, price, and risk of small business credit." Journal of Money, Credit, and Banking.

Berger, Allen N., Lawrence G. Goldberg, and Lawrence J. White. 2001. "The Effects of Dynamic Changes in Bank Competition on the Supply of Small Business Credit," European Finance Review 5: 115-139.

Berger, Allen N., and Timothy H. Hannan. 1998. "The Efficiency Cost of Market Power in the Banking Industry: A Test of the 'Quiet Life' and Related Hypotheses." Review of Economics and Statistics 80: 454-465.

Berger, Allen N. Richard J. Herring, and Giorgio P. Szego. 1995. "The Role of Capital in Financial Institutions." Journal of Banking and Finance 19: 393-430.

Berger, Allen N., Anil K Kashyap, and Joseph M. Scalise. 1995. "The Transformation of the U.S. Banking Industry: What a Long, Strange Trip It's Been.” Brookings Papers on Economic Activity 2: 55-218.

Berger, Allen N., Nathan H. Miller, Mitchell A. Petersen, Raghuram G. Rajan, Jeremy C. Stein. 2002. "Does Function Follow Organizational Form? Evidence From the Lending Practices of Large and Small Banks," NBER Working Paper 8752, National Bureau of Economic Research, Inc. http://papers.nber.org/papers/W8752

Berger, Allen N., Richard J. Rosen, and Gregory F. Udell, 2003. "Does Market Size Structure Affect Competition? The Case of Small Business Lending." Board of Governors of the Federal Reserve System working paper.

Berger, Allen N., Anthony Saunders, Joseph M. Scalise, and Gregory F. Udell. 1998. "The Effects of Bank Mergers and Acquisitions on Small Business Lending." Journal of Financial Economics 50: 187-229.

Berger, Allen N. and Gregory F. Udell. 1990. "Collateral, Loan Quality, and Bank Risk." Journal of Monetary Economics 25: 21-42.

Berger, Allen N. and Gregory F. Udell. 1995. "Relationship lending and lines of credit in small firm finance." Journal of Business 68: 351-382.

Berger, Allen N. and Gregory F. Udell. 1996. "Universal Banking and the Future of Small Business 
Lending," in A. Saunders and I. Walter, ed: Financial System Design: The Case for Universal Banking (Irwin Publishing, Burr Ridge, IL): 559-627. Burr Ridge, IL: Irwin Publishing.

Berger, Allen N. and Gregory F. Udell. 1998. "The Economics of Small Business Finance: The Roles of Private Equity and Debt Markets in the Financial Growth Cycle." Journal of Banking and Finance 22: 613-673.

Berger, Allen N. and Gregory F. Udell. 2002. "Small Business Credit Availability and Relationship Lending: The Importance of Bank Organisational Structure.” Economic Journal 112: F32-F53.

Board of Governors of the Federal Reserve System, Federal Deposit Insurance Corporation, Office of the Comptroller of the Currency, and Office of Thrift Supervision. 2003 "Agencies Announce Publication of Documents Related to Basel Accord Implementation." Joint Press Release and Attachments (August 4). http://www.federalreserve.gov/boarddocs/press/bcreg/2003/20030804/.

Board of Governors of the Federal Reserve System, and U.S. Department of the Treasury. 2000. "The Feasibility and Desirability of Mandatory Subordinated Debt." Report to Congress. http://www.federalreserve.gov/boarddocs/rptcongress/debt/subord_debt_2000.pdf.

Carter, David A., James E. McNulty, and James A. Verbrugge. 2004. "Do Small Banks have an Advantage in Lending?" An Examination of Risk-adjusted Yields on Business Loans at Large and Small Banks, Journal of Financial Services Research 25.

Cole, Rebel A., Lawrence G. Goldberg, and Lawrence J. White. Forthcoming. “Cookie-cutter versus character: The Micro Structure of Small Business Lending by Large and Small Banks." Journal of Financial and Quantitative Analysis.

Diamond, Douglas W. 1991. "Debt Maturity Structure and Liquidity Risk." Quarterly Journal of Economics 106: $709-738$.

Flannery, Mark J. 1986. “Asymmetric Information and Risky Debt Maturity Choice.” Journal of Finance 41: 19-37.

Frame, W. Scott, Aruna Srinivasan, and Lynn Woosley. 2001. "The effect of credit scoring on small business lending." Journal of Money, Credit, and Banking 33: 813-825.

Hancock, Diana, and James A. Wilcox. 1998. "The 'Credit Crunch' and the Availability of Credit to Small Business.” Journal of Banking and Finance 22: 983-1014.

Hannan, Timothy H. 1991. "Bank Commercial Loan Markets and the Role of Market Structure: Evidence from Surveys of Commercial Lending." Journal of Banking and Finance 15: 133-49.

Hannan, Timothy H., and Steven J. Pilloff. 2004. "Will the Proposed Application of Basel II in the United States Encourage Increased Bank Merger Activity? Evidence from Past Merger Activity.” Federal Reserve Board working paper.

Haynes, George W., Charles Ou, and Robert Berney. 1999. Small business borrowing from large and small banks, in Business Access to Capital and Credit, edited by Jackson L. Blanton, Alicia Williams, and Sherrie L.W. Rhine, A Federal Reserve System Research Conference, 287-327. 
Jayaratne, Jith, and John D. Wolken. 1999. "How Important Are Small Banks to Small Business Lending? New Evidence from a Survey of Small Firms." Journal of Banking and Finance 23: 427-58.

Keeton, William R. 1995. Multi-office bank lending to small businesses: Some new evidence, Federal Reserve Bank of Kansas City Economic Review 80 (2): 45-57.

Modigliani, Franco, and Merton Miller. 1958. "The cost of capital, corporation finance, and the theory of investment." American Economic Review 48: 261-297.

Morgan, Donald P., and Adam B. Ashcraft. 2003. "Using Loan Rates to Measure and Regulate Bank Risk: Findings and an Immodest Proposal." Journal of Financial Services Research 24: 181-200.

Peek, Joe and Eric S. Rosengren. 1998. "Bank Consolidation and Small Business Lending: It's Not Just Bank Size That Matters." Journal of Banking and Finance 22: 799-819.

Repullo, Rafael, and Javier Suárez. 2003. "Loan Pricing Under Basel Capital Requirements." Centre for Economic Policy Research Discussion Paper 3917.

Saurina, Jesús, and Carlos Trucharte. 2003. "The impact of Basel II on lending to small-and medium-sized firms. A regulatory policy assessment based on the Spanish Credit Register." Banco de España working paper (June).

Stein, Jeremy C. 2002. "Information Production and Capital Allocation: Decentralized vs. Hierarchical Firms," Journal of Finance 57, 1891-1921.

Strahan, Philip E. and James P. Weston. 1996. "Small business lending and bank consolidation: Is there cause for concern?" Current Issues in Economics and Finance 2, Federal Reserve Bank of New York, 1-6.

Strahan, Philip E. and James P. Weston. 1998. "Small Business Lending and the Changing Structure of the Banking Industry.” Journal of Banking and Finance 22: 821-845.

Williamson, Oliver. 1967. 'The economics of defense contracting: Incentives and performance in issues.' In Defense Economics (ed. R. McKean). New York: Columbia University Press.

Williamson, Oliver. 1988. 'Corporate finance and corporate governance.' Journal of Finance 43: 567-91. 


\begin{tabular}{|c|c|}
\hline \multicolumn{2}{|c|}{$\begin{array}{l}\text { SME lending ratio from June } \\
2002 \text { Call Report }\end{array}$} \\
\hline SME-RATIO & $\begin{array}{l}\text { SME loans for credits } \leq \$ 1 \mathrm{M} \text { divided by gross total } \\
\text { assets (GTA). Replaced by credits } \leq \$ 100 \mathrm{~K}, \$ 100 \mathrm{~K} \text { - } \\
\$ 250 \mathrm{~K} \text {, and } \$ 250 \mathrm{~K} \text { - } \$ 1 \mathrm{M} \text { in robustness checks (K } \\
\text { indicates thousands, and } \mathrm{M} \text { indicates millions). }\end{array}$ \\
\hline \multicolumn{2}{|c|}{$\begin{array}{l}\text { Banking Entity size classes } \\
\text { from June } 2002 \text { Call Report }\end{array}$} \\
\hline Top 20 & $\begin{array}{l}\text { Dummy indicating entity GTA (combined GTA of all the } \\
\text { banks in the top-tier BHC if the bank is in a BHC, and } \\
\text { the GTA of the bank if the bank is independent) in top } 20 \\
\text { as of June } 2002 \text {. Range of entity GTA of approximately } \\
\$ 57.9 \mathrm{~B}-\$ 619.8 \mathrm{~B} \text { (B indicates billions). }\end{array}$ \\
\hline Entities 21-50 & $\begin{array}{l}\text { Dummy indicating entity GTA in Entities } 21-50 \text { as of } \\
\text { June 2002. Range of approximately } \$ 16.8 \mathrm{~B}-\$ 56.2 \mathrm{~B} \text {. }\end{array}$ \\
\hline Other Large & $\begin{array}{l}\text { Dummy indicating entity }>\$ 1 \mathrm{~B} \text {, but not in the top } 50 \text { as } \\
\text { of June } 2002 \text {. Range of approximately } \$ 1.0 \mathrm{~B}-\$ 16.6 \mathrm{~B} \text {. }\end{array}$ \\
\hline Community & $\begin{array}{l}\text { Dummy indicating entity GTA } \leq \$ 1 \mathrm{~B} \text { as of June } 2002 \text {. } \\
\text { Range of approximately } \$ 1 \mathrm{M}-\$ 999 \mathrm{M} \text {. }\end{array}$ \\
\hline \multicolumn{2}{|c|}{$\begin{array}{l}\text { Loan contract terms from } \\
\text { May } 2002 \text { STBL }\end{array}$} \\
\hline PREMIUM & $\begin{array}{l}\text { Premium over the Treasury rate of comparable duration. } \\
\text { Observations for which measured PREMIUM was less } \\
\text { than }-0.01 \text { or greater than } 0.15 \text { were deleted to eliminate } \\
\text { cases of likely gross mismeasurement. }\end{array}$ \\
\hline COLLATERAL & Dummy indicating that the loan is secured by collateral. \\
\hline COMMITMENT & $\begin{array}{l}\text { Dummy indicating that the bank has issued a } \\
\text { commitment on the loan. }\end{array}$ \\
\hline DURATION & $\begin{array}{l}\text { The scheduled time until the principal and interest on the } \\
\text { loan is repaid, discounted using the loan interest rate. }\end{array}$ \\
\hline CREDIT SIZE & $\begin{array}{l}\text { The size of the credit }(\$ 000) \text {, the maximum of the loan } \\
\text { amount and the amount of commitment, if any (i.e., } \\
\text { includes the size of the full line on a line of credit). }\end{array}$ \\
\hline \multicolumn{2}{|c|}{$\begin{array}{l}\text { Loan risk ratings from May } \\
2002 \text { STBL }\end{array}$} \\
\hline RISK-RATING1 & $\begin{array}{l}\text { Dummy equals } 1 \text { if the loan has "minimal" risk (equivalent } \\
\text { to AA rated corporate bond). }\end{array}$ \\
\hline RISK-RATING2 & $\begin{array}{l}\text { Dummy equals } 1 \text { if the loan has "low" risk (equivalent to } \\
\text { BBB rated corporate bond). }\end{array}$ \\
\hline RISK-RATING3 & Dummy equals 1 if the loan has "moderate" risk. \\
\hline RISK-RATING4 & Dummy equals 1 if the loan has "acceptable" risk. \\
\hline RISK-RATING5 & $\begin{array}{l}\text { Dummy equals } 1 \text { if the loan is a special mention or } \\
\text { classified asset. }\end{array}$ \\
\hline
\end{tabular}


Table 2: Means and numbers of observations by banking entity size class for all SME loans $($ CREDIT SIZE $\leq \$ 1 M)$

\begin{tabular}{|c|c|c|c|c|}
\hline & Community & Other Large & $\begin{array}{c}\text { Entities 21- } \\
50\end{array}$ & Top 20 \\
\hline Number of Banks for SME-RATIO & 7520 & 770 & 134 & 130 \\
\hline Number of Banks for Contract Terms & 94 & 75 & 23 & 35 \\
\hline Number of Loans for Contract Terms & 888 & 3871 & 5424 & 11485 \\
\hline Number of Banks for Risk Ratings & 74 & 67 & 19 & 32 \\
\hline Number of Loans for Risk Ratings & 790 & 3497 & 4163 & 9737 \\
\hline SME-RATIO & 0.0805 & 0.0515 & 0.0338 & 0.0214 \\
\hline PREMIUM & 0.0510 & 0.0392 & 0.0354 & 0.0385 \\
\hline COLLATERAL & 0.8131 & 0.8750 & 0.7303 & 0.7753 \\
\hline DURATION & 1.0187 & 0.8954 & 0.8430 & 0.7179 \\
\hline COMMITMENT & 0.7297 & 0.7838 & 0.7703 & 0.8663 \\
\hline CREDIT SIZE & 215.8279 & 242.5586 & 280.6775 & 336.4758 \\
\hline RISK-RATING1 & 0.0633 & 0.0214 & 0.0082 & 0.0177 \\
\hline RISK-RATING2 & 0.2038 & 0.0555 & 0.0617 & 0.0182 \\
\hline RISK-RATING3 & 0.4063 & 0.4226 & 0.1847 & 0.4732 \\
\hline RISK-RATING4 & 0.2962 & 0.4321 & 0.6145 & 0.4043 \\
\hline RISK-RATING5 & 0.0304 & 0.0683 & 0.1309 & 0.0866 \\
\hline Percentage of All Bank SME Loans & $31.86 \%$ & $22.16 \%$ & $11.79 \%$ & $34.19 \%$ \\
\hline
\end{tabular}


Table 3: PREMIUM regressions for all SME loans (CREDIT SIZE $\leq$ \$M)

$\begin{array}{llcc}\text { Variable } & \begin{array}{l}\text { Parameter } \\ \text { Estimate }\end{array} & \text { t Value } & \begin{array}{c}\text { Value for test } \\ \text { of diff. from TOP 20 }\end{array} \\ & & \\ \text { Intercept } & 0.05097 & 100.67 * \star * & \\ \text { OTHER LARGE } & -0.01179 & -21.00 * \star \star & 2.58 \# \# \# \\ \text { ENTITIS 21-50 } & -0.01557 & -28.50 * \star * & -12.28 \# \# \\ \text { TOP 20 } & -0.01252 & -23.81 * \star * & \end{array}$

Num. Obs. 21668 (number of loans with information on contract terms) Adj R-Sq 0.0372

$\begin{array}{lr}\text { Intercept } & 0.07108 \\ \text { OTHER LARGE } & -0.01146 \\ \text { ENTITIES 21-50 } & -0.01525 \\ \text { TOP 20 } & -0.01156 \\ \text { COLLATERAL } & -0.00336 \\ \text { DURATION } & -0.00385 \\ \text { COMMITMENT } & 0.00770 \\ \text { LN (CREDIT SIZE) } & -0.00434\end{array}$

$128.49 * * *$

$-23.18 * * *$

$-31.66 * * *$

$-24.84 * \star \star$

$-14.99 * * *$

$-46.85 * \star \star$

$28.08 * * *$

$-60.43 * * *$
0.40

$-16.73 \# \# \#$

Num. Obs. 21668 (number of loans with information on contract terms) Adj R-Sq 0.2549
Intercept

OTHER LARGE

ENTITIES 21-50

TOP2 0

COLLATERAL

DURATION

COMMITMENT

LN (CREDIT SIZE)

RISK-RATING2

RISK-RATING3

RISK-RATING 4

RISK-RATING5

$$
\begin{array}{r}
0.06399 \\
-0.01280 \\
-0.01585 \\
-0.01267 \\
-0.00467 \\
-0.00361 \\
0.00784 \\
-0.00411 \\
0.00353 \\
0.00864 \\
0.00740 \\
0.00897
\end{array}
$$

$-0.50$

$-12.31 \# \# \#$

$$
\begin{array}{r}
69.37 \star \star \star \\
-24.01 * \star \star \\
-29.94 * \star \star \\
-25.00 * \star \star \\
-17.92 \star \star \star \\
-40.77 \star \star \star \\
26.61 * \star \star \\
-52.07 \star \star \star \\
4.01 * \star \star \\
11.44 * \star \star \\
9.82 \star \star \star \\
11.08 * \star \star
\end{array}
$$

Num. Obs. 18187 (number of loans with risk ratings)

Adj R-Sq 0.2567

* $* *$, and $* * *$ indicate statistically significantly different from 0 at the $10 \%$, 5\%, and 1\% levels (two-sided), respectively.

\#, \#\#, and \#\#\# indicate statistically significantly different from the TOP 20 coefficient at the 10\%, 5\%, and 1\% levels (two-sided), respectively.

The four contract term variables - COLLATERAL, DURATION, COMMITMENT, and LN(CREDIT SIZE) - are jointly significant at the 1\% level.

The four contract term variables and the four risk-rating variables - COLLATERAL, DURATION, COMMITMENT, LN(CREDIT SIZE), RISK-RATING2, RISK-RATING3, RISK-RATING4, and RISK-RATING5 - together, are jointly significant at the 1\% level.

The four risk-rating variables - RISK-RATING2, RISK-RATING3, RISK-RATING4, and RISK-RATING5 - are jointly significant at the 1\% level. 
Table 4: COLLATERAL Logit regressions all SME loans (CREDIT SIZE $\leq$ \$1M)

\begin{tabular}{|c|c|c|c|}
\hline Variable & $\begin{array}{l}\text { Parameter } \\
\text { Estimate }\end{array}$ & Wald $x^{2}$ & $\begin{array}{l}\text { Wald } x^{2} \text { for test } \\
\text { of diff. from TOP } 20\end{array}$ \\
\hline $\begin{array}{l}\text { Intercept } \\
\text { OTHER LARGE } \\
\text { ENTITIES 21-50 } \\
\text { TOP } 20\end{array}$ & $\begin{array}{r}1.4700 \\
0.4756 \\
-0.4740 \\
-0.2317\end{array}$ & $\begin{array}{r}291.6682 * \star \star \\
23.1477 * \star \star \\
0.0914 * \star \star \\
0.0889 * \star \star\end{array}$ & $\begin{array}{r}174.8442 \# \# \# \\
40.8967 \# \# \#\end{array}$ \\
\hline $\begin{array}{l}\text { Num. Obs. } 21668 \\
-2 \text { Log Likelihood }\end{array}$ & 22336.315 & & \\
\hline $\begin{array}{l}\text { Intercept } \\
\text { OTHER LARGE } \\
\text { ENTITIES 21-50 } \\
\text { TOP } 20 \\
\text { DURATION } \\
\text { COMMITMENT } \\
\text { LN (CREDIT SIZE) }\end{array}$ & $\begin{array}{r}0.5023 \\
0.4678 \\
-0.5790 \\
-0.3842 \\
0.0928 \\
0.7461 \\
0.3385\end{array}$ & $\begin{array}{r}24.5096 \star \star \star \\
21.5655 * \star \star \\
38.4681 * \star \star \\
17.7196 \star \star \star \\
32.0506 \star \star \star \\
200.3752 \star \star \star \\
668.2373 \star \star \star\end{array}$ & $\begin{array}{r}240.2435 \# \# \# \\
24.9131 \# \# \#\end{array}$ \\
\hline $\begin{array}{l}\text { Num. Obs. } 21668 \\
-2 \text { Log Likelihood }\end{array}$ & 21632.277 & & \\
\hline $\begin{array}{l}\text { Intercept } \\
\text { OTHER LARGE } \\
\text { ENTITIES 21-50 } \\
\text { TOP 20 } \\
\text { DURATION } \\
\text { COMMITMENT } \\
\text { LN (CREDIT SIZE) } \\
\text { RISK-RATING2 } \\
\text { RISK-RATING3 } \\
\text { RISK-RATING4 } \\
\text { RISK-RATING5 }\end{array}$ & $\begin{array}{r}1.1765 \\
0.6356 \\
-0.2634 \\
-0.6061 \\
0.1046 \\
-0.7689 \\
0.4543 \\
-1.6767 \\
-1.4190 \\
-0.7104 \\
-0.5122\end{array}$ & $\begin{array}{r}26.5412 \star \star \star \\
32.2163 \star \star \star \\
6.1971 * \star \\
36.0242 \star \star \star \\
33.5661 * \star \star \\
172.1409 \star \star \star \\
889.5541 \star \star \star \\
56.5550 * \star \star \\
46.8876 * \star \star \\
11.6731 * \star \star \\
5.4597 \star \star\end{array}$ & $\begin{array}{r}384.4888 \# \# \# \\
44.6899 \# \# \#\end{array}$ \\
\hline
\end{tabular}

* $* *$, and $* * *$ indicate statistically significantly different from 0 at the $10 \%$, 5\%, and 1\% levels (two-sided), respectively.

\#, \#\#, and \#\#\# indicate statistically significantly different from the TOP 20 coefficient at the 10\%, 5\%, and 1\% levels (two-sided), respectively.

The three contract term variables - DURATION, COMMITMENT, and LN(CREDIT SIZE) - are jointly significant at the 1\% level.

The three contract term variables and the four risk-rating variables - DURATION, COMMITMENT, LN(CREDIT SIZE), RISK-RATING2, RISK-RATING3, RISK-RATING4, and RISKRATING5 - together, are jointly significant at the 1\% level.

The four risk-rating variables - RISK-RATING2, RISK-RATING3, RISK-RATING4, and RISK-RATING5 - are jointly significant at the 1\% level. 
Table 5: RISK RATING Ordered Logit regressions for all SME loans (CREDIT SIZE $\leq$ \$1M)

\begin{tabular}{|c|c|c|c|}
\hline Variable & $\begin{array}{l}\text { Parameter } \\
\text { Estimate }\end{array}$ & Wald $x^{2}$ & $\begin{array}{l}\text { Wald } x^{2} \text { for test } \\
\text { of diff. from TOP } 20\end{array}$ \\
\hline $\begin{array}{l}\text { Intercept } 5 \\
\text { Intercept } 4 \\
\text { Intercept } 3 \\
\text { Intercept } 2 \\
\text { OTHER LARGE } \\
\text { ENTITIES 21-50 } \\
\text { TOP 20 }\end{array}$ & $\begin{array}{r}-3.6737 \\
-1.1008 \\
1.5289 \\
2.8069 \\
1.0804 \\
1.9900 \\
1.1545\end{array}$ & $\begin{array}{r}2422.5046 * \star \star \\
246.1829 * \star \star \\
459.8758 * \star \star \\
1108.7052 * \star \star \\
198.9779 * \star \star \\
676.7518 * \star \star \\
255.4028 * \star \star\end{array}$ & $\begin{array}{c}3.9583 \# \# \\
538.7340 \# \# \#\end{array}$ \\
\hline $\begin{array}{l}\text { Num. Obs. } 18187 \\
-2 \text { Log Likelihood }\end{array}$ & 40972.545 & & \\
\hline $\begin{array}{l}\text { Intercept } 5 \\
\text { Intercept } 4 \\
\text { Intercept } 3 \\
\text { Intercept } 2 \\
\text { OTHER LARGE } \\
\text { ENTITIES 21-50 } \\
\text { TOP } 20 \\
\text { COLLATERAL } \\
\text { DURATION } \\
\text { COMMITMENT } \\
\text { LN (CREDIT SIZE) }\end{array}$ & $\begin{array}{r}-3.7993 \\
-1.1903 \\
1.4800 \\
2.7623 \\
1.0292 \\
1.9805 \\
1.2009 \\
0.6148 \\
-0.1345 \\
-0.1054 \\
-0.0444\end{array}$ & $\begin{array}{r}1756.5148 * \star \star \\
187.5121 * \star \star \\
285.2540 * \star \star \\
786.2624 * \star \star \\
179.8805 * \star \star \\
668.6648 * \star \star \\
273.2505 * \star \star \\
276.4784 * \star \star \\
113.0752 \star \star \star \\
6.3049 * \star \\
15.6205 * \star \star\end{array}$ & $\begin{array}{r}20.2595 \# \# \# \\
454.9666 \# \# \#\end{array}$ \\
\hline $\begin{array}{l}\text { Num. Obs. } 18187 \\
-2 \text { Log Likelihood }\end{array}$ & 40565.134 & & \\
\hline
\end{tabular}

*, **, and $* * *$ indicate statistically significantly different from 0 at the $10 \%$, 5\%, and 1\% levels (two-sided), respectively.

\#, \#\#, and \#\#\# indicate statistically significantly different from the TOP 20 coefficient at the 10\%, 5\%, and 1\% levels (two-sided), respectively.

The four contract term variables - COLLATERAL, DURATION, COMMITMENT, and LN(CREDIT SIZE) - are jointly significant at the 1\% level. 
Table 6: Robustness check of means for all SME loans under commitment $($ COMMITMENT $=1$, CREDIT SIZE $\leq \$ 1 M)$

\begin{tabular}{|ccccc|}
\hline & Community & Other Large & $\mathbf{5 0}$ & Top 20 \\
& & & & \\
PREMIUM & 0.0496 & 0.0387 & 0.0367 & 0.0383 \\
COLLATERAL & 0.8549 & 0.8771 & 0.6872 & 0.7853 \\
DURATION & 0.9199 & 0.8247 & 0.8836 & 0.6454 \\
CREDIT SIZE & 277.9971 & 283.6362 & 346.1054 & 375.5647 \\
RISK-RATING1 & 0.0475 & 0.0225 & 0.0108 & 0.0164 \\
RISK-RATING2 & 0.2051 & 0.0534 & 0.0784 & 0.0170 \\
RISK-RATING3 & 0.3797 & 0.4312 & 0.1920 & 0.4720 \\
RISK-RATING4 & 0.3322 & 0.4258 & 0.6032 & 0.4189 \\
RISK-RATING5 & 0.0356 & 0.0672 & 0.1156 & 0.0757 \\
\hline
\end{tabular}


Table 7: Robustness check of means by credit sizes of SME loans (CREDIT SIZE $\leq \$ 100 \mathrm{~K}, \$ 100 \mathrm{~K}-\$ 250 \mathrm{~K}$, and $\$ 250 \mathrm{~K}-\$ 1 \mathrm{M}$ )

\begin{tabular}{|c|c|c|c|c|}
\hline & Community & Other Large & $\begin{array}{c}\text { Entities 21- } \\
50\end{array}$ & Top 20 \\
\hline \multicolumn{5}{|c|}{ CREDIT SIZE $\leq \$ 100 \mathrm{~K}$} \\
\hline SME-RATIO & 0.0337 & 0.0191 & 0.0099 & 0.0086 \\
\hline PREMIUM & 0.0555 & 0.0429 & 0.0380 & 0.0457 \\
\hline COLLATERAL & 0.7412 & 0.8470 & 0.7558 & 0.5905 \\
\hline DURATION & 1.1303 & 0.9319 & 0.9126 & 0.8744 \\
\hline COMMITMENT & 0.5417 & 0.6506 & 0.5689 & 0.7004 \\
\hline CREDIT SIZE & 33.9044 & 41.0196 & 38.5668 & 51.4665 \\
\hline RISK-RATING1 & 0.0822 & 0.0269 & 0.0060 & 0.0174 \\
\hline RISK-RATING2 & 0.2175 & 0.0424 & 0.0750 & 0.0083 \\
\hline RISK-RATING3 & 0.4748 & 0.4205 & 0.1639 & 0.4852 \\
\hline RISK-RATING4 & 0.2095 & 0.4564 & 0.6213 & 0.4006 \\
\hline RISK-RATING5 & 0.0159 & 0.0538 & 0.1338 & 0.0885 \\
\hline \multicolumn{5}{|c|}{ CREDIT SIZE $\$ 100 \mathrm{~K}-\$ 250 \mathrm{~K}$} \\
\hline SME-RATIO & 0.0166 & 0.0099 & 0.0070 & 0.0037 \\
\hline PREMIUM & 0.0480 & 0.0375 & 0.0354 & 0.0376 \\
\hline COLLATERAL & 0.8663 & 0.8986 & 0.7163 & 0.8585 \\
\hline DURATION & 1.1504 & 0.9930 & 0.8829 & 0.7716 \\
\hline COMMITMENT & 0.8663 & 0.8768 & 0.8885 & 0.9162 \\
\hline CREDIT SIZE & 174.3995 & 181.5418 & 186.8121 & 192.0286 \\
\hline RISK-RATING1 & 0.0667 & 0.0197 & 0.0183 & 0.0202 \\
\hline RISK-RATING2 & 0.2121 & 0.0661 & 0.0443 & 0.0154 \\
\hline RISK-RATING3 & 0.4667 & 0.4360 & 0.2339 & 0.4800 \\
\hline RISK-RATING4 & 0.2121 & 0.4233 & 0.5963 & 0.4231 \\
\hline RISK-RATING5 & 0.0424 & 0.0549 & 0.1070 & 0.0612 \\
\hline \multicolumn{5}{|c|}{ CREDIT SIZE \$250K - \$1M } \\
\hline SME-RATIO & 0.0301 & 0.0226 & 0.0168 & 0.0090 \\
\hline PREMIUM & 0.0450 & 0.0345 & 0.0323 & 0.0331 \\
\hline COLLATERAL & 0.9038 & 0.9027 & 0.7053 & 0.8855 \\
\hline DURATION & 0.7357 & 0.7776 & 0.7404 & 0.5701 \\
\hline COMMITMENT & 0.9692 & 0.9280 & 0.9632 & 0.9761 \\
\hline CREDIT SIZE & 562.3003 & 589.4175 & 617.5936 & 626.0756 \\
\hline RISK-RATING1 & 0.0323 & 0.0144 & 0.0067 & 0.0167 \\
\hline RISK-RATING2 & 0.1774 & 0.0683 & 0.0489 & 0.0278 \\
\hline RISK-RATING3 & 0.2621 & 0.4173 & 0.1942 & 0.4601 \\
\hline RISK-RATING4 & 0.4839 & 0.4011 & 0.6123 & 0.3992 \\
\hline RISK-RATING5 & 0.0444 & 0.0989 & 0.1379 & 0.0962 \\
\hline
\end{tabular}


Table 8: Robustness check: Bank GTA, Entity GTA, and SME-RATIO (in descending order) for all SME loans in each of the 130 Top 20 banks (CREDIT SIZE $\leq \$ 1 M$, Banking Entity size class $=$ Top 20)

\begin{tabular}{|c|c|c|c|c|c|c|c|c|c|}
\hline \multirow{2}{*}{$\begin{array}{l}\text { Bank GTA } \\
\text { (\$millions) } \\
706.0\end{array}$} & \multirow{2}{*}{$\begin{array}{l}\text { Entity GTA } \\
\text { (\$millions) } \\
580968.6\end{array}$} & \multicolumn{2}{|c|}{ SME RATIO } & \multicolumn{2}{|c|}{$\begin{array}{l}\text { Bank GTA Entity GTA } \\
\text { (\$millions)(\$millions) }\end{array}$} & \multirow{2}{*}{$\begin{array}{l}\text { SME RATIO } \\
0.0387\end{array}$} & \multirow{2}{*}{$\begin{array}{l}\text { Bank GTA } \\
\text { (\$millions) } \\
20469.5\end{array}$} & \multirow{2}{*}{$\begin{array}{l}\text { Entity GTA } \\
\text { (\$millions) } \\
580968.6\end{array}$} & \multirow{2}{*}{$\begin{array}{l}\text { SME RATIO } \\
0.0049\end{array}$} \\
\hline & & 0.8562 & & 1553.0 & 331850.0 & & & & \\
\hline 257.8 & 580968.6 & 0.6974 & & 7426.8 & 312324.2 & 0.0371 & 2046.5 & 580968.6 & 0.0014 \\
\hline 157.2 & 106224.2 & 0.6117 & & 4618.9 & 312324.2 & 0.0360 & 9054.0 & 580968.6 & 0.0004 \\
\hline 4185.0 & 580968.6 & 0.6061 & & 7175.0 & 331850.0 & 0.0351 & 73705.7 & 73788.7 & 0.0001 \\
\hline 717.4 & 331850.0 & 0.2292 & & 37869.5 & 57883.1 & 0.0340 & 452.9 & 619805.5 & 0.0000 \\
\hline 2810.7 & 173142.5 & 0.1864 & $\sum_{\infty}^{1} \tilde{d}$ & 23607.3 & 331850.0 & 0.0338 & 9315.6 & 607680.7 & 0.0000 \\
\hline 242.9 & 331850.0 & 0.1043 & 年 & 2317.1 & 331850.0 & 0.0333 & 6824.3 & 607680.7 & 0.0000 \\
\hline 84.0 & 80503.3 & 0.1037 & & 41956.5 & 79914.9 & 0.0327 & 92.3 & 607680.7 & 0.0000 \\
\hline 381.5 & 331850.0 & 0.0992 & & 4772.3 & 331850.0 & 0.0305 & 3.2 & 607680.7 & 0.0000 \\
\hline 6077.9 & 580968.6 & 0.0808 & & $\mid 1827.6$ & 80503.3 & 0.0304 & 43276.5 & 580968.6 & 0.0000 \\
\hline 633.9 & 79914.9 & 0.0780 & & 3834.0 & 331850.0 & 0.0303 & 110.6 & 580968.6 & 0.0000 \\
\hline 4114.4 & 57883.1 & 0.0761 & & 2083.1 & 312324.2 & 0.0301 & 27.7 & 580968.6 & 0.0000 \\
\hline 91.1 & 331850.0 & 0.0753 & & 5831.9 & 312324.2 & 0.0288 & 1324.8 & 331850.0 & 0.0000 \\
\hline 842.1 & 331850.0 & 0.0741 & & 106067.0 & 106224.2 & 0.0277 & 469.0 & 331850.0 & 0.0000 \\
\hline 1464.4 & 331850.0 & 0.0741 & & 97.6 & 331850.0 & 0.0267 & 179.7 & 331850.0 & 0.0000 \\
\hline 1285.0 & 79914.9 & 0.0724 & & 14927.0 & 312324.2 & 0.0243 & 9.1 & 331850.0 & 0.0000 \\
\hline 2586.0 & 79914.9 & 0.0715 & & 2990.2 & 62892.3 & 0.0242 & 5.9 & 331850.0 & 0.0000 \\
\hline 339.9 & 80503.3 & 0.0651 & & 59902.1 & 62892.3 & 0.0221 & 3.2 & 331850.0 & 0.0000 \\
\hline 8643.8 & 79914.9 & 0.0633 & & 494757.0 & 580968.6 & 0.0214 & 3.1 & 331850.0 & 0.0000 \\
\hline 24809.6 & 79914.9 & 0.0624 & & 8752.1 & 331850.0 & 0.0209 & 0.3 & 331850.0 & 0.0000 \\
\hline 15889.5 & 57883.1 & 0.0602 & & 206.1 & 113258.6 & 0.0199 & 1832.8 & 312324.2 & 0.0000 \\
\hline 6083.9 & 80503.3 & 0.0599 & & 84868.5 & 84879.2 & 0.0194 & 18.7 & 312324.2 & 0.0000 \\
\hline 1883.8 & 331850.0 & 0.0595 & & 63000.3 & 63000.3 & 0.0190 & 3662.6 & 311176.6 & 0.0000 \\
\hline 82.8 & 331850.0 & 0.0569 & & 18208.1 & 331850.0 & 0.0181 & 291.9 & 311176.6 & 0.0000 \\
\hline 92.4 & 331850.0 & 0.0557 & & 181696.0 & 188132.2 & 0.0179 & 6397.4 & 188132.2 & 0.0000 \\
\hline 360.3 & 113258.6 & 0.0547 & & 20744.7 & 331850.0 & 0.0175 & 38.9 & 188132.2 & 0.0000 \\
\hline 18993.7 & 113258.6 & 0.0506 & & 23451.3 & 607680.7 & 0.0168 & 135.9 & 173142.5 & 0.0000 \\
\hline 2572.7 & 80503.3 & 0.0505 & & 186420.0 & 312324.2 & 0.0167 & 26.5 & 173142.5 & 0.0000 \\
\hline 351.3 & 331850.0 & 0.0489 & & 11194.9 & 331850.0 & 0.0166 & 6.0 & 173142.5 & 0.0000 \\
\hline 3378.2 & 331850.0 & 0.0486 & & 34704.6 & 619805.5 & 0.0160 & 4.4 & 113258.6 & 0.0000 \\
\hline 170163.4 & 173142.5 & 0.0472 & & 304569.0 & 311176.6 & 0.0159 & 10.7 & 84879.2 & 0.0000 \\
\hline 98.5 & 331850.0 & 0.0472 & & 42500.1 & 101362.2 & 0.0153 & 8222.5 & 82288.6 & 0.0000 \\
\hline 2374.1 & 331850.0 & 0.0465 & & 567994.0 & 607680.7 & 0.0135 & 10.1 & 82288.6 & 0.0000 \\
\hline 13907.8 & 113258.6 & 0.0448 & & 2306.1 & 331850.0 & 0.0134 & 451.5 & 79705.1 & 0.0000 \\
\hline 4065.5 & 312324.2 & 0.0447 & & 2997.8 & 312324.2 & 0.0129 & 292.4 & 79705.1 & 0.0000 \\
\hline 15050.8 & 312324.2 & 0.0438 & & 54602.1 & 331850.0 & 0.0122 & 34.9 & 79705.1 & 0.0000 \\
\hline 74056.0 & 82288.6 & 0.0437 & & 342.3 & 312324.2 & 0.0108 & 24.9 & 73788.7 & 0.0000 \\
\hline 10998.8 & 80503.3 & 0.0432 & & 179.4 & 311176.6 & 0.0103 & 23.5 & 73788.7 & 0.0000 \\
\hline 53123.0 & 312324.2 & 0.0428 & & 58862.1 & 101362.2 & 0.0102 & 20.7 & 73788.7 & 0.0000 \\
\hline 149052.0 & 331850.0 & 0.0425 & & 2473.7 & 311176.6 & 0.0092 & 11.6 & 73788.7 & 0.0000 \\
\hline 13585.7 & 312324.2 & 0.0419 & & 32745.6 & 113258.6 & 0.0088 & 2.3 & 73788.7 & 0.0000 \\
\hline 38851.9 & 113258.6 & 0.0407 & & 78926.3 & 79705.1 & 0.0084 & 9.6 & 57883.1 & 0.0000 \\
\hline 8188.7 & 113258.6 & 0.0394 & & 584648.0 & 619805.5 & 0.0064 & & & \\
\hline 58596.5 & 80503.3 & 0.0391 & & 9638.0 & 331850.0 & 0.0054 & & & \\
\hline
\end{tabular}


Table 9: Robustness check: Average PREMIUM (in descending order) for all SME loans in each of the 35 Top 20 banks with Loan Contract Information from the STBL (CREDIT SIZE $\leq \$ 1 M$, Banking

Entity size class $=$ Top 20)

Average Premium

0.0502

0.0425

0.0422

0.0405

0.0403

0.0402

0.0402

0.0384

0.0380

0.0373

0.0368

0.0365

0.0364

0.0359

0.0356

0.0345

0.0338

0.0334

0.0334

0.0325

0.0311

0.0307

0.0305

0.0303

0.0301

0.0295

0.0292

0.0288

0.0287

0.0286

0.0286

0.0274

0.0255

0.0251

0.0239 
Table 10: Robustness check: Average PREMIUM (in descending order, down columns (1), (2), and (3) for all SME loans in each of the 94 Community banks with Loan Contract Information from the STBL (CREDIT SIZE $\leq$ \$1M, Banking Entity size class $=$ Community)

(1) (2)

(3)

Average Premium Average Premium Average Premium

\begin{tabular}{|c|c|c|}
\hline 0.086828 & 0.054844 & 0.044267 \\
\hline 0.082322 & 0.054575 & 0.044232 \\
\hline 0.076499 & 0.053995 & 0.044012 \\
\hline 0.072998 & 0.053771 & 0.044002 \\
\hline 0.070927 & 0.053237 & 0.043657 \\
\hline 0.070413 & 0.053168 & 0.043363 \\
\hline 0.069923 & 0.052841 & 0.043311 \\
\hline 0.069257 & 0.051555 & 0.043096 \\
\hline 0.066526 & 0.050645 & 0.043003 \\
\hline 0.066253 & 0.050624 & 0.041897 \\
\hline 0.065946 & 0.050488 & 0.041132 \\
\hline 0.064062 & 0.050319 & 0.04076 \\
\hline 0.063129 & 0.05007 & 0.040502 \\
\hline 0.062741 & 0.049243 & 0.039984 \\
\hline 0.061823 & 0.049133 & 0.039914 \\
\hline 0.060701 & 0.048991 & 0.039773 \\
\hline 0.060502 & 0.048844 & 0.039624 \\
\hline 0.060357 & 0.048762 & 0.038946 \\
\hline 0.059994 & 0.048601 & 0.037626 \\
\hline 0.059861 & 0.048321 & 0.037198 \\
\hline 0.059837 & 0.047869 & 0.035716 \\
\hline 0.059452 & 0.047008 & 0.033855 \\
\hline 0.059345 & 0.046994 & 0.033588 \\
\hline 0.058955 & 0.04674 & 0.032685 \\
\hline 0.058472 & 0.045791 & 0.031513 \\
\hline 0.057278 & 0.04577 & 0.03117 \\
\hline 0.056891 & 0.04555 & 0.029226 \\
\hline 0.056443 & 0.045415 & 0.02466 \\
\hline 0.056359 & 0.044949 & 0.024263 \\
\hline 0.056319 & 0.044849 & 0.021103 \\
\hline 0.055475 & 0.044428 & 0.044267 \\
\hline 0.055024 & 0.044269 & 0.044232 \\
\hline
\end{tabular}

